\title{
AAV Vectored Immunoprophylaxis for Filovirus Infections
}

\author{
Amira D. Rghei, Laura P. van Lieshout, Lisa A. Santry, Matthew M. Guilleman, Sylvia P. Thomas, \\ Leonardo Susta $\mathbb{D}^{\mathbb{D}}$, Khalil Karimi ${ }^{\mathbb{D}}$, Byram W. Bridle $\mathbb{D}^{\mathbb{D}}$ and Sarah K. Wootton *(D)
}

Department of Pathobiology, Ontario Veterinary College, University of Guelph, Guelph, ON N1G 2W1, Canada; arghei@uoguelph.ca (A.D.R.); lvanlies@uoguelph.ca (L.P.v.L.); 1santry@uoguelph.ca (L.A.S.); guillemm@uoguelph.ca (M.M.G.); sthoma13@uoguelph.ca (S.P.T.); lsusta@uoguelph.ca (L.S.); kkarimi@uoguelph.ca (K.K.); bbridle@uoguelph.ca (B.W.B.)

* Correspondence: kwootton@uoguelph.ca

Received: 1 October 2020; Accepted: 6 November 2020; Published: 9 November 2020

\begin{abstract}
Filoviruses are among the deadliest infectious agents known to man, causing severe hemorrhagic fever, with up to $90 \%$ fatality rates. The 2014 Ebola outbreak in West Africa resulted in over 28,000 infections, demonstrating the large-scale human health and economic impact generated by filoviruses. Zaire ebolavirus is responsible for the greatest number of deaths to date and consequently there is now an approved vaccine, Ervebo, while other filovirus species have similar epidemic potential and remain without effective vaccines. Recent clinical success of REGN-EB3 and mAb-114 monoclonal antibody $(\mathrm{mAb})$-based therapies supports further investigation of this treatment approach for other filoviruses. While efficacious, protection from passive $\mathrm{mAb}$ therapies is short-lived, requiring repeat dosing to maintain therapeutic concentrations. An alternative strategy is vectored immunoprophylaxis (VIP), which utilizes an adeno-associated virus (AAV) vector to generate sustained expression of selected $\mathrm{mAbs}$ directly in vivo. This approach takes advantage of validated $\mathrm{mAb}$ development and enables vectorization of the top candidates to provide long-term immunity. In this review, we summarize the history of filovirus outbreaks, mAb-based therapeutics, and highlight promising AAV vectorized approaches to providing immunity against filoviruses where vaccines are not yet available.
\end{abstract}

Keywords: monoclonal antibodies; adeno-associated virus vector; vectored-immunoprophylaxis (VIP); vector biology; filoviruses; viral hemorrhagic fever; zoonotic diseases

\section{Introduction}

Infectious diseases have had profound and long-lasting impacts on the human race throughout history. Epidemic threats are deepened by the emergence of new and uncharacterized infectious diseases, coupled with the ability to impact human health and the economy at a global scale. Although our understanding and surveillance of infectious disease has advanced, the pursuit of effective methods for preventing the spread of these infections at times remains elusive. Filovirus disease outbreaks showcase these concerns, due to their high pathogenicity, zoonotic transmission efficiency, and spontaneity of spillover. Although Ebola hemorrhagic fever (EHF) and Marburg hemorrhagic fever (MHF) are highly pathogenic viral diseases, the global burden of EHF and MHF is minor in comparison to other infectious diseases [1]; however, as we observed with the 2014 West Africa outbreak, EHF has the potential to cause large, multi-nation outbreaks resulting in significant mortality and economic devastation. In this review, we will discuss the history and pathogenesis of filoviruses, highlight the role of antibodies in protection against filovirus infections, and examine the potential of viral vector-mediated expression 
of monoclonal antibodies (mAbs) as an alternative prophylactic strategy to enable long term passive immunity against filovirus infections.

\section{Filoviruses}

\subsection{A Brief History of Filovirus Outbreaks}

Filovirus outbreaks have been reported since 1967, with the first outbreak of Marburg virus (MARV) occurring simultaneously in Germany and Yugoslavia, when laboratory workers imported African green monkeys (Chlorocebus aethiops) from Uganda and were exposed while working with the tissues of infected animals [2]. The second outbreak of Marburg virus disease (MVD) occurred in 1975 in South Africa, where it was determined that the index patient had visited caves in Rhodesia (now Zimbabwe) and had come in contact with bats [3]. A subsequent Marburg outbreak occurred in Kenya in 1987, where the index case had also visited a cave and contracted the virus; however, in this case the disease was caused by a new strain of Marburgvirus; Ravn virus (RAVV). In total, there have been 13 recorded MARV outbreaks (MARV and RAVV) with over 460 confirmed cases and 370 reported deaths [4].

Shortly after the discovery of MARV, there were three outbreaks of Sudan ebolavirus (SUDV) and Zaire Ebolavirus (EBOV) in 1976, across Sudan, the Democratic Republic of Congo (DRC) (formerly Zaire), and England [5]. Since the identification of Ebola virus in 1976, there have been a total of 38 Ebola virus disease (EVD) outbreaks, including the recent EBOV outbreak in the DRC, which was announced 1 June 2020 [6]. The largest filovirus outbreak occurred from December 2013 to March 2016, shedding light on the true epidemic potential of EBOV. Epidemiological and genomic analyses suggest that the index case was a 2-year old boy in Meliandou, Guinea, who had been infected through exposure to bats [7]. By the time multiple cases of fatal diarrhea were reported and the Pasteur Institute had confirmed EBOV was the cause, the disease had already spread to the capital of Guinea, Conakry [8], as well as to neighboring countries, Sierra Leone and Liberia. On 23 March 2014, the WHO officially declared an outbreak of EVD. Inadequate disease surveillance, poor public health infrastructure, the ravages of civil war, extreme poverty, and local customs, such as washing a dead body prior to burial, aided in the spread of EBOV $[9,10]$. After more than two years, the outbreak was declared over in June of 2016, claiming the lives of more than 11,320 people and infecting a staggering 28,600 individuals [11]. The unprecedented scale of this outbreak left many survivors suffering from post-Ebola syndrome [12], orphaned more than 17,000 children [13], and devastated economies. Moreover, the EVD outbreak reduced the availability of treatments and monitoring for other serious infectious diseases, including HIV, tuberculosis, and malaria leading to increased mortality [14]. Despite the fact that previous filovirus outbreaks had highlighted the potential for efficient transmission and high case fatality rates, there were no U.S Food and Drug Administration (FDA)-approved vaccines or therapeutics for EBOV prior to the 2014 West Africa Ebola outbreak.

\subsection{Filovirus Taxonomy}

Filoviruses are a family of non-segmented, negative-sense RNA viruses belonging to the order Mononegavirales. Filovirus taxonomy has been frequently updated during the past decade, where the most recent update by the International Committee on Taxonomy of Viruses in July of 2019 listed six genera and eleven species in the family [15]. The six genera within the Filoviridae family include: Ebolavirus, Marburgvirus, Cuevavirus, Thamnovirus, and Striavirus, and the most recently classified, Dianlovirus [16,17]. The Ebolavirus genus contains six species: the highly pathogenic Zaire ebolavirus (EBOV, Ebola virus) and Sudan ebolavirus (SUDV, Sudan virus), the less prevalent Taï forest ebolavirus (TAFV, Taï Forest virus), Bundibugyio virus (BDBV, Bundibugyio virus), Reston ebolavirus (RESTV, Reston virus), and the recently discovered Bombali ebolavirus (BOMV, Bombali virus) [18]. The genus Marburgvirus contains a single species, Marburg marburgvirus (MARV, Marburg virus); however, two distinct strains with less than $30 \%$ genetic divergence, Marburg virus (MARV) and Ravn virus (RAVV), make up this species [19]. Lloviu cuevavirus (LLOV, Lloviu virus), isolated from insectivorous bats located in Northern Spain, 
is the only species confirmed in the Cuevavirus genus [20]. Of the members in the Filoviridae family, seven species have been confirmed to infect humans, including EBOV, SUDV, TAFV, BDBV, MARV, RESTV, and RAVN, albeit with different severity [21]. The most virulent is EBOV, followed closely by MARV with fatality rates ranging from $25-90 \%$ and $24-88 \%$, respectively, whereas, BDBV and SUDV are less severe with fatality rates of $\sim 30 \%$ and $50 \%$, respectively [21-23]. Though RESTV does cause infections in humans, these have only ever been reported as asymptomatic; however, it can be fatal in non-human primates (NHP) [24]. Limited information is known about TAFV infections in humans as there has only been one documented case, with that person recovering after a severe illness [25].

\subsection{Filovirus Molecular Biology and Pathogenesis}

Filoviruses are filamentous enveloped particles $80 \mathrm{~nm}$ in diameter and up to $14,000 \mathrm{~nm}$ in length [26]. The negative-sense, single stranded RNA genome is approximately $19 \mathrm{~kb}$ in length and encodes seven open reading frames (ORF) orientated in a $3^{\prime}-5^{\prime}$ direction: the nucleoprotein (NP), viral protein (VP) 35, VP40, glycoprotein (GP), VP30, VP24, and the RNA-dependent RNA polymerase (L) [27]. Each ORF is flanked by non-translated regions including conserved transcriptional start and stop signals crucial for protein expression [28,29]. The GP for filoviruses is the only protein "studded" on the surface of the virion and is the sole determinant of viral entry into host cells [30]. In addition to the fundamental role of the GP in viral entry, ebolavirus GPs appear to have multiple auxiliary functions, likely contributing to the complex pathogenesis of the virus [31].

As humans are not the natural reservoir hosts for filoviruses, spillover occurs through contact with the virus's natural reservoir hosts, which in the case of EBOV is likely to be a species of bat [32]. Alternatively, transmission can occur through contact with intermediate hosts, for instance when hunting bushmeat, or through secondary transmission by infected humans. In patients with disease, acute EBOV and MARV virus shedding occurs and can be found in blood or other bodily fluids including: urine, saliva, sweat, feces, vomit, breast milk, and semen [33]. Once an individual becomes infected there is a 2-21 day incubation period, with calculated mean incubation periods of 5.3-12.7 days for EBOV, 3.35-12 days for SUDV, and 6.3-7 days for BDBV, characterized by onset of non-specific flu-like symptoms [34-40]. Following this incubation period, disease occurs rapidly in lethal cases, with high fever, severe hemorrhage, shock, followed by death, due to systemic viral replication, immunosuppression, and abnormal inflammatory responses with extensive organ distribution [41-43]. Upon entering the host, filoviruses preferentially infect antigen presenting cells (APCs) including dendritic cells (DCs), monocytes, and macrophages [44-47]. Infected APCs fail to activate and mature and are therefore unable to present antigens to $\mathrm{T}$ cells in the lymph nodes. Upregulation of co-stimulatory molecules (i.e., CD40, CD80, CD86, and MHC class II) is inhibited in infected APCs, which subsequently interferes with their ability to initiate adaptive immune responses $[48,49]$. Additionally, studies have shown that infection of EBOV and MARV results in lymphopenia, affecting CD4+ and CD8+ T cells, as well as B cells and natural killer cells [50-52]. Loss of B cells, as well as helper T cells, leads to impairment in humoral responses, as there is an absence of specific IgG and barely detectable IgM in fatal infections [53]. Conversely, Ebola survivors have revealed significant activation of both B and T cells, proliferating plasmablasts, as well as circulating Ebola virus-specific IgG $[54,55]$.

\section{Filovirus Vaccine Development}

After the first Ebola virus outbreak in 1976, research began on an inactivated EBOV vaccine, which was shown to be efficacious in guinea pigs in 1980 [56]. Due to the sporadic nature of the outbreaks and the low number of confirmed cases, development of a vaccine against EBOV was not a high priority prior to the 2014 West Africa outbreak. However, since 2014, the reality of the public health threat imposed by EBOV has been brought to the forefront. Of the 97 National Institute of Health (NIH) clinical trials for EVD, 88 were registered after 1 January 2014. Additionally, several vaccine platforms against MVD have shown pre-clinical efficacy in NHPs, including DNA vaccines, virus-like particles, 
recombinant adenovirus vectors, and recombinant vesicular-stomatitis virus (VSV), with multiple successful phase I clinical trials [57-60].

With the increased efforts and resources in developing a vaccine for EBOV as of 2014, there is now an FDA approved vaccine for EBOV. The vaccine produced by Merck, VSV-ZEBOV, is a live, attenuated recombinant VSV expressing the GP of Zaire ebolavirus. This vaccine was initially developed by the Public Health Agency of Canada (PHAC) in 2001, known as V920 during its investigational phase, and was licensed by a subsidiary of NewLink Genetics Corp in 2010. In late 2014, with the 2014 West Africa Ebola outbreak at its peak, Merck acquired the rights to develop this vaccine. V920, later trade named Ervebo, was deployed in a "ring vaccination" trial and was determined to be $100 \%$ efficacious against EVD [61]. In November 2019, the European Commission granted conditional marketing approval, and within $48 \mathrm{~h}$, the WHO approved the vaccine's prequalification. The FDA approved the vaccine in December 2019, and as of June 2020, over 300,000 people in the DRC and surrounding countries have been vaccinated. Although Ervebo received fast-track approval during the 2018 Ebola outbreak in the DRC, limiting the spread of the outbreak, the history of EVD outbreaks previously demonstrated the need to develop a vaccine against EBOV long before either the 2014 or the 2018 Ebola outbreaks. Furthermore, while EBOV has been responsible for the greatest number of infections and deaths to date, other filoviruses have demonstrated through past outbreaks that they have similar epidemic potential.

To overcome the lack of funding and resources for developing vaccines against other members of the filovirus family, alternative solutions are being investigated to combat these viruses. Monoclonal antibodies (mAbs) are an accepted treatment for infectious diseases, especially for those which lack an effective vaccine. Passive antibody administration is an effective method for providing rapid immunity to susceptible individuals against a specific pathogen as a pre- and a post-exposure prophylaxis. Although passively administering potent $m A b s$ against infectious agents can confer protection, it is not long-lasting and requires repeat dosing for long-term efficacy. An alternative approach to the traditional passive transfer antibodies is to utilize human cells directly in vivo to "manufacture" neutralizing mAbs, by vectorizing antibody expression. With the use of highly potent, and well characterized mAbs specific for not only EBOV, but other members of the filovirus family, potential to develop a pan-filovirus cocktail of AAV-mAbs to protect individuals against future outbreaks remains untapped.

\section{Filovirus Monoclonal Antibodies and the Potential of Antibody Therapy}

\subsection{Murine Derived Monoclonal Antibodies}

The first attempt to use antibodies for passive immunization involved administration of convalescent serum, dating back as early as the 1940 [62]. Low concentrations of antibodies as well as safety concerns around convalescent serum led to the development of mAbs, providing well characterized, safer, and documented sources of pathogen-specific antibodies. An ever-increasing panel of mAbs have been investigated for Ebola virus neutralization activity in both pre- and post-exposure scenarios in a variety of animal models, including mice, guinea pigs, ferrets, and NHPs [63-68]. mAbs-based therapies have been shown to be efficient at reversing the progression of a lethal Ebola virus infection in NHPs, which closely recapitulates the disease in humans [69-72]. Past studies have demonstrated that the humoral immune response correlates with survival and plays a critical role in protection [73,74].

Earlier studies in BALB/c mice immunized with VSV pseudotyped with the EBOV GP (VSV $\triangle \mathrm{G} / \mathrm{ZEBOVGP}$ ) resulted in the generation of $\mathrm{mAbs} 1 \mathrm{H} 3,2 \mathrm{G} 4,4 \mathrm{G} 7,5 \mathrm{D} 2,5 \mathrm{E} 6,7 \mathrm{C} 9,7 \mathrm{G} 4$, and 10C8 [75]. These murine mAbs exhibited high-affinity binding to diverse domains on the GP protein, with some possessing neutralizing activity. mAbs 5D2, 5E6 and 7C9, which bind to the heavily glycosylated mucin-like domain (MLD) [76], and IH3, which binds the glycan cap, are non-neutralizing and likely rely on effector functions to be confered protection, while neutralizing mAbs 2G4 and 4G7 bind within the GP1-GP2 interface potentially preventing structural changes required for membrane fusion [77]. Following challenge with $1000 \times \mathrm{xD}_{50}$ mouse-adapted Zaire ebolavirus (MA-ZEBOV), mAbs 5D2, 5E6, 
7C9, and 7G4 provided $100 \%$ protection in mice, and neutralizing mAbs $2 \mathrm{G} 4$ and $4 \mathrm{G} 7$ conferred $60 \%$ protection in the guinea pig model [66]. ZMab, a cocktail of 1H3, 2G4, and 4G7, was able to completely protect NHPs when the first of three doses of the cocktail was administered $24 \mathrm{~h}$ pre-exposure to EBOV [78].

MB-003, a cocktail comprised of 13C6, 13F6, and 6D8, was generated from mice immunized with Venezuelan equine encephalitis virus replicons encoding the GP from EBOV [79]. Murine antibody variable regions were subsequently chimerized with human IgG constant regions and produced in tobacco (Nicotiana benthamiana) [80,81]. MB-003 mAbs were individually able to confer protection both one day prior and one day-post exposure to 300xLD 50 -MA-EBOV [81]. Furthermore, 13F6 and 6D8 bind the MLD with high affinity, despite being unable to neutralize, while $13 \mathrm{C} 6$ binds the glycan cap of GP but does not neutralize [79]. In an NHP study, $67 \%$ protection resulted from administration of MB-003, either 24 or $48 \mathrm{~h}$ post-infection with a lethal dose of EBOV with no apparent adverse effects or viremia from infection in those NHPs that survived [71].

Optimization of various $\mathrm{mAb}$ combinations led to the development of ZMapp, a combination of $2 \mathrm{G} 4$ and 4G7 from ZMab and 13C6 from MB-003 [82]. ZMapp administration five days post-exposure to EBOV challenge resulted in rescue of 100\% of NHPs. High fever, viremia, and coagulation abnormalities, elevated liver enzymes, mucosal hemorrhages, and generalized petechia were developed by the NHPs prior to ZMapp administration, which was reversed, leading to full recovery [82]. During the 2014 West Africa Ebola outbreak, ZMapp was granted fast track approval from the FDA and a randomized, controlled trial of ZMapp was conducted nearing the end of the epidemic. Of the 72 individuals enrolled in the trial, there was a $30 \%$ overall case fatality rate, with $37 \%$ fatality from those who received standard care alone and $22 \%$ fatality from those who received standard care plus ZMapp [83]. Although ZMapp appeared to be more beneficial than standard care alone, the trial did not enroll a sufficient number of participants to reach statistical significance [83].

While effective, the first generation of EBOV mAbs were generated in mice, which has some disadvantages for human administration. For example, murine mAbs are swiftly degraded in human circulation as they cannot undergo antibody recycling and can cause an anti-drug antibody (ADA) humoral response $[84,85]$. Engineering murine mAbs to more closely resemble human antibodies, referred to as chimeric antibodies (chAbs) or humanized antibodies (huAbs), can potentially alleviate ADA immune responses [86]. huAbs are less likely to incite an immune response in humans and NHPs than murine or chimeric antibodies, making them attractive immunotherapies when therapeutics can be administered at high dosages and potentially more than once [87-89]; however, antibody isolation techniques have enabled identification of mAbs directly from human samples, providing even less risk of ADA.

\subsection{Human Derived Monoclonal Antibodies}

In more recent years, screening of human B cells from survivors of filovirus infection has led to the isolation and characterization of potent mAbs showing therapeutic effects in animal models as monotherapies or in cocktails [82,90,91]. Two potent mAbs, 100 and 114, were characterized from the serum of human survivors of the 1995 Kikwit outbreak more than a decade later [92]. Furthermore, 100 binds to the base of the GP, and is likely to compete with 2G4 and 4G7 of ZMapp, while mAb 114 binds in the same region of the glycan cap as $13 \mathrm{C} 6$ of ZMapp; however, mAb 114 is neutralizing [90]. Strikingly, monotherapy of 114 or in a cocktail with mAb 100 was $100 \%$ protective in NHPs challenged with a lethal dose of EBOV 3-5 days post infection [90]. mAb 114 was tested in a phase I clinical trial for safety, tolerability, pharmacokinetics, and immunogenicity, showing no adverse reactions at the time of injection, $22 \%$ of individuals reporting mild reactogenicity within the first four days, and no long-term solicited adverse events post injection in the participants [93]. In a randomized, controlled phase II clinical trial, mAb 114 was compared against the mAb cocktails ZMapp and REGN-EB3 (invented by Regeneron) as well as remdesivir, a broad-spectrum antiviral. After the enrollment and administration to 681 consenting laboratory-confirmed EVD patients, it was recommended 
based on the positive results of the interim analysis that patients be assigned only to the MAb114 and REGN-EB3 groups for the remainder of the trial [83]. Though proven protective against EVD, both mAb Mab114 and REGN-EB3 protection does not extend to other members of the filovirus family.

As with EBOV, MARV GP-specific neutralizing antibodies have been shown to reduce mortality after challenge with a lethal dose of MARV [69]. One of the many antibodies isolated from a human survivor of MARV (Table 1), MR191 protected NHPs challenged with a lethal dose of MARV when administered intravenously either 4 or 7 days post challenge [94]. MR191 neutralizes MARV through competing with Niemann-Pick C1 (NPC1) for the receptor-binding site (RBS) on MARV [95]. Additionally, some of these MARV mAbs have the ability to cross-react with EBOV GP. MR78, MR111, and MR191 bind EBOV GP lacking the glycan cap and MLD, while MR72 binds the full EBOV GP as well as variants [95]. Although seven clinical trials investigating various methods of treatment and prevention of MVD have been registered with clinicaltrials.gov, none of these studies have evaluated the use of mAbs $[58-60,96]$. 
Table 1. Top performing mAbs for MARV from human survivors.

\begin{tabular}{|c|c|c|c|c|c|c|c|}
\hline & Antibody and Source & Target & Competes with & Cross-Binds & Cross Neutralizes & Protection & Reference \\
\hline MR72 & $\begin{array}{l}\text { Human IgG1; } \\
\text { Survivor from 2014 } \\
\text { MARV outbreak } \\
\text { in Uganda }\end{array}$ & $\begin{array}{c}\text { Receptor-binding site } \\
\text { (RBS) near } \\
\text { the hydrophobic } \\
\text { trough and the apex } \\
\text { of GP1 }\end{array}$ & $\begin{array}{l}\text { MR78, MR82, } \\
\text { MR191 }\end{array}$ & $\begin{array}{c}\text { MARV (all strains), } \\
\text { EBOV GP }\end{array}$ & $\begin{array}{l}\text { MARV (Uganda), } \\
\text { RAVV }\end{array}$ & $\begin{array}{l}\text { 100\% protective in mice } \\
(\mathrm{n}=5) \text { against MARV } \\
\text { (Uganda) in mice }\end{array}$ & [95] \\
\hline M78 & $\begin{array}{l}\text { Human IgG1; } \\
\text { Survivor from 2014 } \\
\text { MARV outbreak } \\
\text { in Uganda }\end{array}$ & $\begin{array}{c}\text { Binds to the top } \\
\text { and side of GP1 at a } \\
\text { shallow angle relative } \\
\text { to the central } \\
\text { three-fold axis }\end{array}$ & $\begin{array}{l}\text { MR72, MR82, } \\
\text { MR191 }\end{array}$ & $\begin{array}{l}\text { MARV (Uganda) } \\
\text { and RAVV }\end{array}$ & $\begin{array}{l}\text { MARV (Uganda } \\
\text { and Ravn), potentially } \\
\text { neutralizes EBOV } \\
\text { entry by inhibiting } \\
\text { viral membrane fusion } \\
\text { downstream from } \\
\text { virus receptor } \\
\text { recognition }\end{array}$ & $\begin{array}{l}100 \% \text { protective in guinea } \\
\text { pigs against MARV } \\
\text { (Angola) and } 100 \% \\
\text { against RAVV }\end{array}$ & {$[95,97]$} \\
\hline MR82 & $\begin{array}{l}\text { Human IgG1; } \\
\text { Survivor from 2014 } \\
\text { MARV outbreak } \\
\text { in Uganda }\end{array}$ & $\begin{array}{l}\text { Binds toward the top } \\
\text { and side of GP1 at a } \\
\text { shallow angle relative } \\
\text { to the central } \\
\text { three-fold axis }\end{array}$ & $\begin{array}{l}\text { MR72, MR78, } \\
\text { MR191 }\end{array}$ & MARV (all strains) & MARV (all strains) & $\begin{array}{l}40 \% \text { protective in guinea } \\
\text { pigs; however, it was } \\
100 \% \text { effective in mice }\end{array}$ & [95] \\
\hline MR191 & $\begin{array}{l}\text { Human IgG1; } \\
\text { Survivor from 2014 } \\
\text { MARV outbreak } \\
\text { in Uganda }\end{array}$ & $\begin{array}{c}\text { RBS near } \\
\text { the hydrophobic } \\
\text { trough and the apex } \\
\text { of GP1 }\end{array}$ & $\begin{array}{l}\text { MR72, MR78, } \\
\text { MR82 }\end{array}$ & $\begin{array}{c}\text { MARV (Muskoke } \\
\text { and Angola), RAVV, } \\
\text { EBOV GP (does not } \\
\text { neutralize) }\end{array}$ & $\begin{array}{c}\text { MARV (Angola } \\
\text { and Muskoke) }\end{array}$ & $\begin{array}{l}100 \% \text { protective against } \\
\text { MARV (Angola) } \\
\text { and RAVV in guinea pigs. } \\
100 \% \text { effective in NHPs } \\
\text { when treated on day } 4 \\
\text { and } 7 \text { post infection } \\
\text { (MARV Angola). } 80 \% \\
\text { protective on days } 5 \text { and } 8 \\
\text { post infection of RAVV. } \\
\text { Did not protect against } \\
\text { GPA-SUDV in guinea pig } \\
\text { models } 3 \text { dpi }\end{array}$ & {$[94,95,98]$} \\
\hline
\end{tabular}




\subsection{Pan-Ebolavirus Monoclonal Antibodies}

Since the 2014 West Africa Ebola outbreak, an increase in highly potent mAbs have been isolated and characterized, with some providing pan-ebolavirus protection (Table 2) [99]. This class of antibodies shows cross-species binding of GP and in some cases neutralizes multiple filoviruses. CA45, an mAb developed through immunizing NHPs with a trivalent GP cocktail (EBOV/SUDV/MARV GP $\left.{ }_{\triangle \text { mucin }}\right)$, generated antibodies that bound and neutralized pseudotyped VSV displaying EBOV, SUDV, or BDBV GP [99]. CA45 binds the internal fusion loop of the N-terminus of GP and rapidly neutralizes EBOV, SUDV, BDBV, and RESTV [100]. CA45 targets a conserved epitope at the base of the GP in close proximity to EBOV-specific mAbs, 2G4 and 4G7 [100]. However, CA45 binds at a slightly different angle, allowing for better binding to both $\mathrm{GP}_{1}$ and $\mathrm{GP}_{2}$, partially inhibiting GP cleavage at an earlier step in viral fusion as well as blocking the virus post GP cleavage. Furthermore, CA45 alone or in combination with FVM04 provided full protection at a low dose $(10 \mathrm{mg} / \mathrm{kg})$ against EBOV, SUDV, and BDBV in mouse, guinea pig, and ferret animal models [100,101]. FVM04 in combination with 13C6 and 2G4 demonstrated increased survival in a lethal guinea pig adapted (GPA)-EBOV challenge compared to ZMapp, and extended survival against GPA-SUDV challenge, demonstrating the cross-protective nature of this antibody cocktail [101].

ADI-15878 is a potent neutralizing mAb isolated from a survivor of the 2014 West Africa Ebola outbreak that binds the highly conserved region of $\mathrm{GP}_{2}$, locking GP into a pre-fusion state as well as targeting a cleaved intermediate prior to viral fusion [102]. ADI-15878 provided $100 \%$ protection in mouse models of EBOV and SUDV infection; however, it was only partially protective against EBOV and SUDV in guinea pig and ferret models [102-104]. ADI-15946 is another potent pan-ebolavirus antibody that neutralizes VSV pseudotyped with GPs from EBOV, BDBV, and SUDV. ADI-15946 was specificity-matured for SUDV GP binding affinity using yeast-display technology and the resultant variant, named ADI-23774, was combined with ADI-15878 to form the pan-ebolavirus cocktail MBP134. MBP134 potently neutralized EBOV, BDBV, SUDV, TAFV, RESTV, and BOMV pseudotyped VSVs and protected $70-100 \%$ of guinea pigs five days post-challenge with GPA-SUDV [104]. MBP134 demonstrates limitless engineering and advancements of filovirus-specific mAbs, allowing for the potential development of a potent pan-filovirus mAb cocktail. 
Table 2. Top performing pan-Ebola mAbs from human survivors.

\begin{tabular}{|c|c|c|c|c|c|c|c|}
\hline & $\begin{array}{l}\text { Antibody } \\
\text { and Source }\end{array}$ & Target & Competes with & Cross-Binds & Cross Neutralizes & Protection & Reference \\
\hline CA45 & $\begin{array}{c}\text { Macaque; } \\
\text { Immunized } \\
\text { macaque against } \\
\text { EBOV, SUDV } \\
\text { and MARV GPs }\end{array}$ & $\begin{array}{l}\text { Conserved epitope in } \\
\text { the internal fusion loop. } \\
\text { Binds to the native GP but } \\
\text { binds with way higher } \\
\text { potency to the cleaved GP. } \\
\text { Does not bind soluble GP } \\
\text { (sGP) }\end{array}$ & $\begin{array}{l}\text { KZ52, 2G4 } \\
\text { and } 4 \mathrm{G} 7\end{array}$ & $\begin{array}{l}\text { EBOV, SUDV } \\
\text { and BDBV (does } \\
\text { not bind MARV, } \\
\text { Tai Forest or } \\
\text { LLOV) }\end{array}$ & $\begin{array}{l}\text { Potently neutralizes EBOV, } \\
\text { SUDV, and BDBV } \\
\text { and moderately neutralizes } \\
\text { Reston. IC50 for EBOV } \\
\text { and cleaved core } \\
\text { ectodomain of EBOV } \\
\text { (EBOV GPcl) was } 4.63 \\
\text { and } 0.05 \mathrm{nM} \text {, BDBV } \\
\text { and GPcl was } 4.24 \text { and } 0.007 \\
\text { nM, and SUDV and GPcl } \\
\text { was } 9.16 \text { and } 0.05 \mathrm{nM}\end{array}$ & $\begin{array}{l}\text { In mice }(\mathrm{n}=20) \text {, protection } \\
\text { was as good as against } \\
\text { EBOV and } 80 \% \text { against } \\
\text { SUDV. In guinea pigs }(\mathrm{n}=6) \\
\text { it was } 100 \% \text { protective } \\
\text { against EBOV and SUDV. } \\
100 \% \text { protection in ferret } \\
\text { model }(\mathrm{n}=4) \text { of BDBV. } \\
\text { FVM04 + CA } 45 \text { in mice } \\
\text { against SUDV was } 100 \% \\
\text { effective, mirrored in guinea } \\
\text { pigs for EBOV }\end{array}$ & [100] \\
\hline BDBV223 & $\begin{array}{l}\text { Human IgG3; } \\
\text { Human survivor } \\
\text { of } 2007 \text { Uganda } \\
\text { BDBV outbreak }\end{array}$ & $\begin{array}{l}\text { GP2 stalk (canonical heptad } \\
\text { repeat } 2 \text { (HR2) domain near } \\
\text { the MPER) (71\% conserved } \\
\text { amongst the five first } \\
\text { Ebolaviruses, and } 90 \% \\
\text { conserved amongst EBOV, } \\
\text { BDBV, and SUDV), does not } \\
\text { recognize BDBV sGP }\end{array}$ & $\begin{array}{l}\text { BDBV317, } \\
\text { BDBV340 }\end{array}$ & $\begin{array}{l}\text { rVSV-GP of EBOV, } \\
\text { BDBV, and SUDV }\end{array}$ & $\begin{array}{l}\text { rVSV-GP of EBOV, BDBV, } \\
\text { and SUDV }\end{array}$ & $\begin{array}{c}100 \% \text { in mice }(\mathrm{n}=5), \\
\text { post-exposure }(1 \text { day) was } \\
20 \% \text { protection against } \\
\text { lethal EBOV (Mayinga) } \\
\text { challenge in guinea pigs } \\
(\mathrm{n}=5) \text { and } 50 \% \text { effective in } \\
\text { ferret models }(\mathrm{n}=4), 3- \\
\text { and } 6 \text {-days post-challenge }\end{array}$ & [104-106] \\
\hline FVM04 & $\begin{array}{l}\text { Cloned as human } \\
\text { IgG1 with kappa } \\
\text { light chain; } \\
\text { Macaque } \\
\text { vaccinated with } \\
\text { EBOV, SUDV, } \\
\text { and MARV GP }\end{array}$ & $\begin{array}{l}\text { The exposed tip of } \\
\text { the receptor binding } \\
\text { domain crest at the apex of } \\
\text { the GP trimer and blocks } \\
\text { interaction of GP with } \\
\text { NPC1 in the late endosome. } \\
\text { Glycans may moderately } \\
\text { interfere with optimal } \\
\text { binding. The RBD crest is } \\
\text { highly conserved }\end{array}$ & $\begin{array}{l}\text { M13C6, partially } \\
\text { KZ52 }\end{array}$ & $\begin{array}{c}\text { EBOV, SUDV, } \\
\text { and BDBV (Binds } \\
\text { WT, cleaved } \\
\text { and sGP of all } \\
\text { Ebola species), low } \\
\text { affinity binding to } \\
\text { MARV and Reston }\end{array}$ & $\begin{array}{c}\text { EBOV and SUDV but not } \\
\text { really BDBV or MARV. It is } \\
\text { a weaker neutralization } \\
\text { than some others: EC50 of } \\
4.3 \text { and } 4.3 \mathrm{ug} / \mathrm{mL} \text { for SUDV } \\
\text { and EBOV }\end{array}$ & $\begin{array}{c}100 \% \text { in mice against EBOV } \\
\text { and } 75 \% \text { in mice against } \\
\text { SUDV. } 100 \% \text { protective in } \\
\text { guinea pigs against SUDV } \\
\text { and } 40 \% \text { protective against } \\
\text { EBOV }\end{array}$ & {$[101,107]$} \\
\hline ADI-15742 & $\begin{array}{l}\text { Human IgG; } \\
\text { Human survivor } \\
\text { of } 2014 \text { West } \\
\text { Africa outbreak }\end{array}$ & $\begin{array}{l}\text { A highly conserved region } \\
\text { of GP2 within the internal } \\
\text { fusion loop. Locks the GP } \\
\text { into a pre-fusion state } \\
\text { whether free or bound to } \\
\text { NPC1. Does not bind sGP }\end{array}$ & $\begin{array}{l}\text { ADI-15878, 100, } \\
\text { KZ52, CA45 }\end{array}$ & $\begin{array}{c}\text { Everything but } \\
\text { MARV/LLOV } \\
\text { (rVSV-GP for each } \\
\text { Ebolavirus } \\
\text { and Marburgvirus) }\end{array}$ & $\begin{array}{l}\text { Potently neutralizes all five } \\
\text { Ebola virus with IC50 of } \\
<2 \mathrm{nM} \text { for rVSV } \\
\text { pseudotypes }\end{array}$ & $\begin{array}{c}100 \% \text { protection in lethal } \\
\text { mouse model (100 } \mu \mathrm{g} \\
\text { against } 100 \text { pfu MA-EBOV) } \\
\text { The two ADIs are clonal } \\
\text { siblings with } 90 \% \text { and } 95 \% \\
\text { chain identity. }\end{array}$ & [102] \\
\hline
\end{tabular}


Table 2. Cont.

\begin{tabular}{|c|c|c|c|c|c|c|c|}
\hline & $\begin{array}{c}\text { Antibody } \\
\text { and Source }\end{array}$ & Target & Competes with & Cross-Binds & Cross Neutralizes & Protection & Reference \\
\hline ADI-15878 & $\begin{array}{l}\text { Human IgG; } \\
\text { Human survivor } \\
\text { of } 2014 \text { West } \\
\text { Africa outbreak }\end{array}$ & $\begin{array}{l}\text { A highly conserved region } \\
\text { of GP2 within the internal } \\
\text { fusion loop. Locks the GP } \\
\text { into a pre-fusion state } \\
\text { whether free or bound to } \\
\text { NPC1. Does not bind sGP. } \\
\text { Seems to target a cleaved } \\
\text { intermediate in endosomes } \\
\text { while first generation base } \\
\text { binders act further } \\
\text { upstream }\end{array}$ & 100, KZ52, CA45 & $\begin{array}{l}\text { Everything but } \\
\text { MARV/LLOV }\end{array}$ & $\begin{array}{c}\text { Potently neutralizes all five } \\
\text { Ebola virus with IC50 of }<2 \\
\text { nM for rVSV pseudotypes }\end{array}$ & $\begin{array}{c}80 \% \text { protective in mice } \\
(\mathrm{n}=10) \text { against } \mathrm{EBOV} \\
\text { and } 100 \% \text { protective in mice } \\
(\mathrm{n}=20) \text { against SUDV. } 75 \% \\
\text { protective against BDBV in } \\
\text { ferrets }(\mathrm{n}=4)\end{array}$ & [102] \\
\hline ADI-23374 & $\begin{array}{l}\text { Derived from } \\
\text { affinity maturation } \\
\text { of a human mAb } \\
\text { (Human survivor } \\
\text { of } 2014 \text { West } \\
\text { Africa outbreak } \\
\text { ADI-15946) using } \\
\text { yeast resulting in } \\
\text { enhanced potency } \\
\text { against SUDV. }\end{array}$ & $\begin{array}{l}\text { ADI- } 15946 \text { binds a highly } \\
\text { conserved epitope shielded } \\
\text { by the mobile } \beta 17-\beta 18 \text { loop } \\
\text { of the glycan cap, which is } \\
\text { where ADI- } 23774 \text { binds, } \\
\text { does not bind sGP of EBOV }\end{array}$ & $\begin{array}{l}\text { EBOV, BDBV, } \\
\text { SUDV }\end{array}$ & $\begin{array}{l}\text { EBOV, BDBV, } \\
\text { SUDV }\end{array}$ & rVSV-SUDV GP & $\begin{array}{l}90 \% \text { protective against } \\
\text { EBOV in mice }(\mathrm{n}=10) \\
3 \text { days post exposure } \\
\text { and was } 100 \% \text { protective } \\
\text { against wt-SUDV in mice } \\
\text { (IFNR-/- mice) }(\mathrm{n}=10) \text { at } 1- \\
\text { and } 4 \text {-days post exposure }\end{array}$ & [108] \\
\hline
\end{tabular}

* They appear to bind the exact same location, although ADI-15878 engenders viral neutralization escape to a lesser extent than ADI-15742. 


\section{AAV-Mediated Monoclonal Antibody Expression for Filovirus Infections}

\subsection{AAV-Mediated Monoclonal Antibody Expression}

FDA approval of AAV-based gene therapy products Luxterna (voretigene neparovec) and Zolgensma (onasemnogene abeparvovec) has dramatically accelerated the clinical progression of AAV therapeutics $[109,110]$. AAV vectors have an established record of high-efficiency gene transfer in a variety of model systems [111]. When delivered to post-mitotic organs including muscle, brain, and liver, $\mathrm{AAV}$ vector genomes assume the form of intranuclear high-molecular weight episomal concatamers that direct transgene expression for extended periods of time [112,113]. Vectored immunoprophylaxis (VIP), a term first coined by David Baltimore and colleagues [114], is used to describe AAV-mediated delivery of $\mathrm{mAb}$ genes (Figure 1). AAV mAbs are typically expressed as full-length antibodies with heavy and light chain sequences separated by an F2A self-cleaving peptide containing a furin recognition sequence between the heavy chain gene and $2 \mathrm{~A}$, which allows for removal of $2 \mathrm{~A}$ residues from the upstream gene $[114,115]$. Administration of AAV expressing genes encoding well characterized pathogen specific mAbs leads to continuous and sustained secretion of antibodies into the blood stream resulting in protection against a wide range of potential infectious agents [116]. This strategy has been shown to be highly effective at protecting mice against both systemic and mucosal HIV infection as well as protecting rhesus macaques against systemic simian immunodeficiency virus (SIV) infection $[114,117,118]$. In these studies, AAV expressed mAbs were detected in the circulation at therapeutic levels for the lifetime of the host after only a single IM injection [114]. Delivery of AAV-encoded HIV mAbs 10-1074, 3BNC117, and 10E8 to rhesus macaques that had been infected with SHIV-AD8 for 86 weeks prior to receiving AAV therapy showed proof of concept that AAV-delivered $m A b s$ have the potential to provide a functional cure for HIV [119]. Evaluations of bNAb levels after AAV administration revealed that 10E8 was low or undetectable in all animals, 3BNC117 was delivered successfully in one out of four animals and 10-1074 achieved significant expression levels in three out of four NHPs. Although ADA responses led to a decline in mAb expression, one monkey successfully maintained $50-150 \mu \mathrm{g} / \mathrm{mL}$ of 10-1074 and 3BNC117 for more than two years and controlled SHIV viremia for over three years, demonstrating the power of VIP [119]. In a recent report, a macaque that received a single injection of an AAV vector encoding the anti-SIV antibody 5L7 achieved high levels of serum 5L7 IgG1 expression ( $240-350 \mu \mathrm{g} / \mathrm{mL})$ for over six years and this conferred sterile protection against six successive, escalating dose, intravenous challenges with highly pathogenic SIVmac239, including a final challenge with 10 animal infectious doses [120]. Importantly, this NHP generated little or no ADA to the AAV-delivered $\mathrm{mAb}$ for the duration of the study.

While the initial application of VIP was for the prevention of HIV, subsequent infectious disease applications have been explored including influenza virus, malaria, and HCV [114,117,121-125] among others. For example, AAV vectors encoding broadly neutralizing influenza antibodies demonstrated protection in mice against multiple influenza virus strains following a single IM injection and this protection was sustained one year after AAV administration [121]. Notably, immunodeficient and aged mice as well as ferrets were protected by this method, suggesting that AAV-mediated mAb expression is sufficient to protect from influenza-induced illness in a variety of animal models [126]. This broad range of successful pre-clinical applications justified the expansion of this platform to target filovirus diseases where potent neutralizing $\mathrm{mAbs}$ have previously been isolated and characterized as reviewed above. 


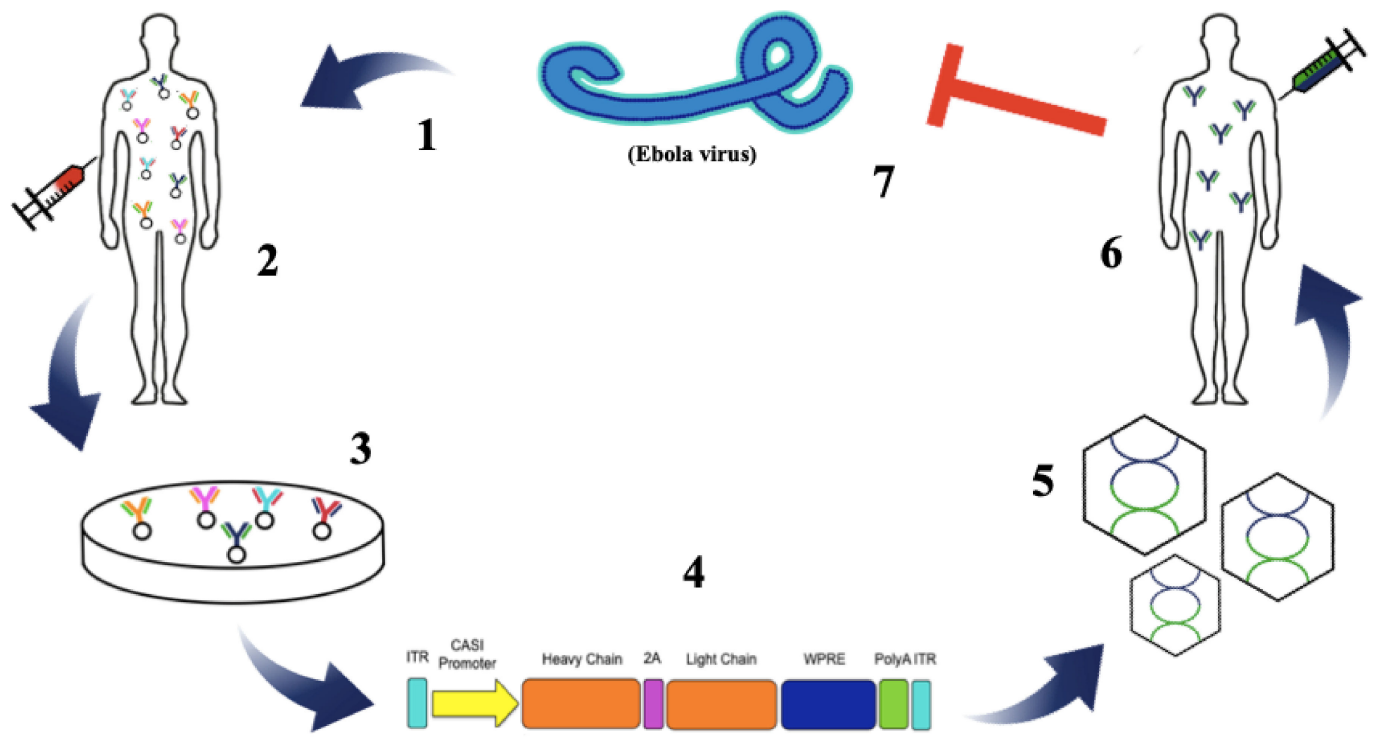

Figure 1. Schematic representation of adeno-associated virus vectored-immunoprophylaxis (AAV VIP) against Ebolavirus. Ebolavirus infects a healthy patient causing the onset of Ebola hemorrhagic fever (EHF) (1). B cells are isolated from the blood of an Ebola virus disease (EVD) survivor (2). Potent antibodies are isolated for further development and characterization (3). Variable-heavy and variable-light chains of selected mAbs are cloned into the AAV vector (4). AAV vectors expressing the potent mAb against ebolavirus are manufactured (5). Individuals susceptible to ebolavirus infection are intramuscularly administered $A A V-m A b$ vector (6). mAbs are secreted from the AAV-mAb transduced muscle cells into the blood stream and circulate throughout the blood, protecting against ebolavirus infection (7).

\subsection{Pre-Clinical Models of AAV-Mediated Monoclonal Antibody Expression and Protection against Filovirus Infections}

Currently, a limited number of groups have published data on AAV-mediated expression of $m A b s$ for the treatment and prevention of filovirus infections. Although this is not a traditional vaccine approach, the goal of employing AAV-mediated $\mathrm{mAb}$ expression for filoviruses is to generate long-term immunity for populations at risk of being exposed to the virus during outbreaks. The first group to evaluate this approach utilized AAV9 to express murine mAbs, 2G4, 4G7, and 13C6, which were previously successful in the treatment of EBOV in macaques [78,127]. Following intranasal administration of vector, mice were protected from a lethal challenge of EBOV, while intramuscular administration was hampered by systemic immune responses against the chimeric mouse/human antibodies. Humanizing the mAbs in the cocktail resulted in sustained $\mathrm{mAb}$ expression and a two-fold increase in $\mathrm{mAbs}$ in the serum and bronchoalveolar lavage fluid [128]. This group indicated that intravenous administration may potentially result in higher transgene expression than traditional intramuscular routes of VIP administration. Additionally, they indicated that an antibody-specific humoral response limits protective efficacy, indicating that capsid and antibody gene selection is critical to minimize humoral immune responses for successful VIP therapeutics. Our group utilized a novel AAV6 variant, termed AAV6.2FF, to deliver 2G4, 5D2, and 7C9 mAb genes to the muscle demonstrating that non-neutralizing $\mathrm{mAb}$ VIP monotherapies alone can confer $100 \%$ protection against lethal EBOV infection in mice $[66,116]$. A minimum of seven days lead time was required for VIP administration to provide $100 \%$ protection from lethal EBOV challenge in mice, indicating that this approach may provide protective immunity more rapidly than traditional vaccinations. Finally, AAV-mediated mAb expression from a single administration given five months prior to lethal challenge with MA-EBOV protected $100 \%$ of the mice demonstrating the potential of this VIP platform to be used as an alternative vaccination strategy for filovirus diseases. Ultimately, the VIP approach to filovirus prevention still requires optimization, but currently represents a promising area for filovirus disease prevention. 


\subsection{Clinical Relevance}

Many late-stage clinical trials are currently underway studying the effects of AAV-based gene therapy on a variety of genetic diseases including alpha-1 antitrypsin deficiency and hemophilia B [129-131]. The safety profile and efficacy shown in the outcomes of these trials among others have paved the way for many AAV therapies to enter the clinic including those that are using VIP for the prevention and treatment of HIV [124]. Promising results in animal models of SIV and HIV following rAAV administration encoding broadly neutralizing antibodies and immunoadhesins have driven $\mathrm{AAV}$-mediated $\mathrm{mAb}$ producing therapies forward into clinical evaluation as an alternative to long-term recombinant $\mathrm{mAb}$ re-administration [132]. One of the current clinical trials involves AAV-mediated antibody gene delivery for the prevention of HIV infection (NCT01937455) using rAAV1 to deliver mAb PG9 [124]. PG9 was previously found to be highly potent, able to neutralize a broad panel of HIV strains, and achieved 90\% inhibition of a diverse set of HIV-1 viruses at concentrations far lower than competing broadly neutralizing antibodies. During the course of the trial, a singular mild adverse event due to the treatment regimen suggests that the use of AAV-mediated gene transfer represents a safe method of therapeutic delivery in healthy individuals that does not differ from the safety profile of a preventative vaccine [124]. However, very low PG9 expression was observed, suggesting that the AAV serotype, expression strategy, antibody selection, and immune response mitigation must be optimized for future studies. Another phase I clinical trial is underway (NCT03374202) examining the delivery of a potent broadly neutralizing HIV antibody, VRC07, utilizing AAV8 for targeted gene delivery to the muscle in HIV patients using a vector system that differs minimally from those outlined in the filovirus VIP pre-clinical study data [117]. The outcomes of these clinical studies for HIV will inform future platform development for filovirus VIP therapies $[110,133]$.

\subsection{Benefits of the AAV VIP Approach}

In vivo delivery of $\mathrm{mAb}$ genes for pre-or post-exposure prophylaxis offers an alternative to conventional vaccines and passive immunization. With the VIP, there is little need to understand complex correlates of immunity as in vaccine development; one simply needs the sequence of a protective $\mathrm{mAb}$ which are often available well before effective vaccines. AAV-mAb expression provides less expensive and longer lasting immunity than passive immunization and would be a useful tool in the event of a filovirus virus outbreak, particularly for ring vaccination purposes. VIP circumvents the lead time required for vaccine induced adaptive immunity to mount before being effective. Since $\mathrm{AAV}-\mathrm{mAb}$ expression results in production of protective antibodies independent of the immune system, it can be employed to protect individuals who do not respond to traditional vaccination or who are lacking a properly functioning immune system, such immunocompromised, elderly or pediatric populations. VIP is an ideal stop gap measure for intervention in outbreaks where a vaccine is unavailable (e.g., MARV and SUDV) and could provide a synergistic effect in combination with a traditional vaccine to combine the benefits of both immunization strategies. Moreover, AAV is a remarkably stable vector that can be lyophilized to facilitate long-term stockpiles as well as formulated to negate cold chain requirements for transportation [134].

\subsection{AAV VIP Challenges and Potential Solutions}

Although AAV vector-mediated delivery of mAbs holds great promise for treating and preventing infectious diseases that lack effective vaccines, including filovirus infections, there are a number of potential hurdles that still need to be addressed. For example, in NHP models of AAV VIP for HIV $[118,120,135,136]$, as well as in the first human clinical trial in which AAV was used to express the broadly neutralizing HIV mAb, PG9 [124], ADAs were detected and this correlated with loss of mAb expression. However, broadly neutralizing HIV Abs (bNAbs) appear after several years of infection and are known to exhibit an unusually high rate of somatic hypermutation with frequencies of up to $32 \%$ in the heavy chain variable region and extended complementarity-determining regions [137-139]. 
In contrast, the number of mutations observed in influenza antibodies rarely exceeds $10 \%$ and in the case of VSV, early primary response VSV-neutralizing IgGs are free of somatic mutations [140,141]. Currently, it is unknown whether such highly mutated regions in HIV bNAbs make them targets of anti-drug antibody responses or whether the same would occur with mAbs with fewer somatic mutations. It would be interesting to compare AAV-mediated gene transfer efficacy and the extent of ADA formation against an HIV bNAb such as PG9 or 10E8 and a filovirus antibody such as MR191 in a large animal model since up to this point, the only AAV-mAbs that have been evaluated in NHPs have been broadly neutralizing HIV or SIV mAbs [95,142-144]. Finally, a recent SHIV-AD8 challenge study in macaques found that the formation of ADAs was more pronounced when AAV-expressed mAbs were of the IgG1 isotype, which has been the default isotype for AAV VIP, rather than IgG2, suggesting that optimization of the mAb isotype may limit the formation of ADA [145].

Host immune responses to the AAV vector itself have been shown to limit the ability to attain therapeutic concentrations of AAV expressed mAbs. In the first human clinical trial involving AAV VIP, both anti-AAV1 capsid antibodies and AAV1-capsid specific T-cell responses were detected [124]. Recently, systemic co-administration of AAV vectors with poly(lactic acid) (PLA) nanoparticles containing rapamycin (SVP(Rapa)) was shown to efficiently block the induction of both antibody and $T$ cell anti-capsid responses in an antigen (i.e., AAV capsid) specific manner [146-148]. Pre-existing neutralizing antibodies to the AAV capsid may also reduce the efficacy of AAV VIP therapies; however, a recent report by Elmore and colleagues describes a clinically relevant strategy to rapidly and transiently degrade neutralizing AAV capsid antibodies prior to AAV administration [149-152]. In this case, a single intravenous dose of the IgG-degrading enzyme, IdeZ, rescued AAV transduction by transiently reversing seropositivity, mitigating the effects of preexisting anti-AAV NAbs in mice and NHPs [153]. Finally, engineering of novel AAV variants with reduced neutralizing antibody recognition is another approach being used to circumvent preexisting humoral immunity to AAV vectors [154,155].

In some circumstances, such as in pediatric patients with rapid tissue growth, re-administration may be required. While some serotypes of AAV can be efficiently re-administered if the time between administrations is longer than 28 weeks [156,157], a number of studies have reported successful re-administration after pretreatment of the host with immunosuppressing antibodies [158-161], for example, B cell depleting monoclonal antibody, rituximab [162,163], immune-modulating agents [164], or broad immunosuppressing agents, such as cyclophosphamide [165].

The ability of AAV vectors to achieve long-term transgene expression has been attributed to their relatively low immunogenicity [166-168]; however, AAV vectors have been shown to activate various Toll like receptors (TLRs) and this can have an influence on the outcome of gene transfer [169,170]. In particular, the AAV DNA genome and capsid are sensed by TLR9 and TLR2, respectively [171,172], and AAV vectors carrying double-stranded genomes show higher immunogenicity relative to those carrying single-stranded genomes [173]. Recent findings also suggest that CpG sequences in the AAV genome contribute to transgene immunogenicity but that $\mathrm{CpG}$-depletion of AAV vectors can promote persistent transgene expression and minimize infiltration of effector cells that target AAV-transduced cells $[173,174]$. Although these observations were made using preclinical animal models, factors such as CG dinucleotides that influence transgene immunogenicity should be carefully evaluated as part of the clinical translation pipeline.

Lastly, apart from the waning of mAb expression due to natural turnover of AAV transduced cells, there are currently no FDA-approved methods for turning off expression of AAV-mAbs once administered, should there be a need. Developing a "kill-switch", where administration of a protein could inhibit further expression of AAV-mAbs would be an added safety measure and may allow for the application of short-term AAV VIP therapies [175]. Finally, though AAV VIP may offer more sustained and consistent $\mathrm{mAb}$ expression than traditional passive immunization, the cost of producing AAV vectors is not insignificant. 
The next few years should provide improvements to AAV mAb gene delivery that will ultimately reveal whether AAV VIP is a viable platform for expressing therapeutic levels of protective mAbs in both preventive and therapeutic contexts.

\section{Future Directions}

The concept of VIP was first established in 2002 [125]; however, it is only more recently that this approach has been expanded to infections beyond HIV and clinical evaluation has begun [125]. Further vector design improvements to maximize mAb expression including selection of regulatory elements in the vector genome (i.e., promoter, poly adenylation signal) and antibody expression sequence (i.e., leader peptide, codon optimization) as well as targeting specific cell types of interest through capsid engineering or tissue specific promoters will enable indication-specific optimization of the VIP platform.

We and others have demonstrated AAV-mediated expression of mAbs against Ebola virus to be an effective method of protecting mouse models from lethal infection. To date, these studies have focused on EBOV specific antibodies; however, there are a number of more recent publications highlighting the availability of mAbs able to bind and neutralize multiple species of Ebolavirus including EBOV, SUDV, and BDBV, which will enable the development of pan-ebolavirus $m A b$ cocktails $[100,103,104,108]$. Furthermore, mAbs that bind to both EBOV and MARV have been identified creating the possibility of pan-filovirus $\mathrm{mAb}$ therapies, although cross-neutralizing antibodies for both these filoviruses remain elusive $[71,95,176]$.

The antibody engineering field has generated dozens of innovative designs for therapeutic antibodies to facilitate a variety of desired functions [177]. The packaging capacity of AAV facilitates the generation of vectors expressing bispecific antibodies such as dual variable domain immunoglobulins (DVD-Igs) [178]. Conversely, multidomain antibodies string together a number of single domain antibodies or nanobodies to facilitate binding to numerous epitopes while DVD-Igs are limited to two [179]. Both of these strategies enable the expression of multiple antigen binding fragments, which establishes multivalent targeting of diverse species or epitopes using a single vector. In the context of filoviruses, bispecific or multidomain antibodies in combination with pan-filovirus activity could result in a VIP product capable of providing protection against all filovirus infections in a single product.

Here we reviewed the VIP platform with a focus on filoviruses; however, there are a number of parallels with other infectious diseases affecting populations in poverty with poor health care infrastructure, insignificant funding for research and development of prophylactics or therapeutics and a lack of licensed vaccines, which is still the case for all but one of the pathogenic filoviruses despite more attention in recent years. The aim of the VIP platform is to confer long term expression of protective mAbs to facilitate immunity against infection, whether the target is a filovirus, HIV, or any other infectious disease of public health importance, the methodology is the same and learnings from one indication can be applied to new pathogens in the future.

Author Contributions: Conceptualization, A.D.R., L.P.v.L., and S.K.W.; writing-original draft preparation, A.D.R., L.P.v.L., L.A.S., M.M.G., S.P.T., L.S., K.K., B.W.B., and S.K.W.; writing-review and editing, L.P.v.L. and S.K.W.; supervision, S.K.W. All authors have read and agreed to the published version of the manuscript.

Funding: Funding was provided by NSERC Discovery Grant number RGPIN-2018-04737.

Acknowledgments: We would like to thank Matthew Stiver for his contribution to the schematic shown in Figure 1.

Conflicts of Interest: The authors declare no conflict of interest. The funders had no role in the design of the review; in the writing of the manuscript, or in the decision to publish. 


\section{References}

1. MacNeil, A.; Rollin, P.E. Ebola and Marburg hemorrhagic fevers: Neglected tropical diseases? PLoS. Negl. Trop. Dis. 2012, 6. [CrossRef]

2. Martini, G.A.; Knauff, H.G.; Schmidt, H.A.; Mayer, G.; Baltzer, G. A hitherto unknown infectious disease contracted from monkeys. "Marburg-virus" disease. Ger. Med. Mon. 1968, 13, 457-470. [PubMed]

3. Gear, J.S.; Cassel, G.A.; Gear, A.J.; Trappler, B.; Clausen, L.; Meyers, A.M.; Kew, M.C.; Bothwell, T.H.; Sher, R.; Miller, G.B.; et al. Outbreake of Marburg virus disease in Johannesburg. Br. Med. J. 1975, 4, 489-493. [CrossRef] [PubMed]

4. Outbreaks Chronology: Marburg Hemorrhagic Fever. Available online: https://www.cdc.gov/vhf/marburg/ outbreaks/chronology.html (accessed on 26 February 2020).

5. Emond, R.T.; Evans, B.; Bowen, E.T.; Lloyd, G. A case of Ebola virus infection. Br. Med. J. 1977, 2, 541-544. [CrossRef] [PubMed]

6. New Ebola Outbreak Detected in Northwest Democratic Republic of the Congo; WHO Surge Team Supporting the Response. Available online: https://www.who.int/news-room/detail/01-06-2020-new-ebola-outbreakdetected-in-northwest-democratic-republic-of-the-congo-who-surge-team-supporting-the-response (accessed on 30 September 2020).

7. Marí Saéz, A.; Weiss, S.; Nowak, K.; Lapeyre, V.; Zimmermann, F.; Düx, A.; Kühl, H.S.; Kaba, M.; Regnaut, S.; Merkel, K.; et al. Investigating the zoonotic origin of the West African Ebola epidemic. EMBO. Mol. Med. 2015, 7, 17-23. [CrossRef] [PubMed]

8. 2014-2016 Ebola Outbreak in West Africa. Available online: https://www.cdc.gov/vhf/ebola/history/20142016-outbreak/index.html (accessed on 2 March 2020).

9. Alexander, K.A.; Sanderson, C.E.; Marathe, M.; Lewis, B.L.; Rivers, C.M.; Shaman, J.; Drake, J.M.; Lofgren, E.; Dato, V.M.; Eisenberg, M.C.; et al. What factors might have led to the emergence of Ebola in West Africa? PLoS. Negl. Trop. Dis. 2015, 9. [CrossRef]

10. Factors That Contributed to Undetected Spread of the Ebola Virus and Impeded Rapid Containment. Available online: http://www.who.int/entity/csr/disease/ebola/one-year-report/factors/en/index.html (accessed on 28 May 2020).

11. Coltart, C.E.M.; Lindsey, B.; Ghinai, I.; Johnson, A.M.; Heymann, D.L. The Ebola outbreak, 2013-2016: Old lessons for new epidemics. Philos. Trans. R. Soc. Lond. B. Biol. Sci. 2017, 372, 20160297. [CrossRef]

12. Wilson, H.W.; Amo-Addae, M.; Kenu, E.; Ilesanmi, O.S.; Ameme, D.K.; Sackey, S.O. Post-Ebola syndrome among Ebola virus disease survivors in Montserrado County, Liberia 2016. Biomed. Res. Int. 2018, 1909410. [CrossRef]

13. Cost of the Ebola Epidemic. Available online: https://www.cdc.gov/vhf/ebola/history/2014-2016-outbreak/ cost-of-ebola.html (accessed on 9 March 2020).

14. Parpia, A.S.; Ndeffo-Mbah, M.L.; Wenzel, N.S.; Galvani, A.P. Effects of response to 2014-2015 Ebola outbreak on deaths from malaria, HIV/AIDS, and tuberculosis, West Africa. Emerg. Infect. Dis. 2016, 22, $433-441$. [CrossRef]

15. Mononegavirales. Available online: https://talk.ictvonline.org/ictv-reports/ictv_online_report/negativesense-rna-viruses/mononegavirales/w/filoviridae (accessed on 29 May 2020).

16. Hume, A.J.; Mühlberger, E. Distinct genome replication and transcription strategies within the growing filovirus family. J. Mol. Biol. 2019, 431, 4290-4320. [CrossRef] [PubMed]

17. Yang, X.-L.; Tan, C.W.; Anderson, D.E.; Jiang, R.-D.; Li, B.; Zhang, W.; Zhu, Y.; Lim, X.F.; Zhou, P.; Liu, X.-L.; et al. Characterization of a filovirus (Měnglà virus) from Rousettus bats in China. Nat. Microbiol. 2019, 4, $390-395$. [CrossRef] [PubMed]

18. Goldstein, T.; Anthony, S.J.; Gbakima, A.; Bird, B.H.; Bangura, J.; Tremeau-Bravard, A.; Belaganahalli, M.N.; Wells, H.L.; Dhanota, J.K.; Liang, E.; et al. The discovery of Bombali virus adds further support for bats as hosts of ebolaviruses. Nat. Microbiol. 2018, 3, 1084-1089. [CrossRef]

19. Brauburger, K.; Hume, A.J.; Mühlberger, E.; Olejnik, J. Forty-five years of Marburg virus research. Viruses 2012, 4, 1878-1927. [CrossRef] [PubMed]

20. Negredo, A.; Palacios, G.; Vázquez-Morón, S.; González, F.; Dopazo, H.; Molero, F.; Juste, J.; Quetglas, J.; Savji, N.; de la Cruz Martínez, M.; et al. Discovery of an Ebolavirus-like Filovirus in Europe. PLoS. Pathog. 2011, 7, e1002304. [CrossRef] 
21. Languon, S.; Quaye, O. Filovirus disease outbreaks: A chronological overview. Virology 2019, 10. [CrossRef]

22. Ebola Virus Disease. Available online: https://www.who.int/news-room/fact-sheets/detail/ebola-virus-disease (accessed on 12 May 2020).

23. Marburg Virus Disease. Available online: https://www.who.int/news-room/fact-sheets/detail/marburg-virusdisease (accessed on 12 May 2020).

24. Yuan, J.; Zhang, Y.; Li, J.; Zhang, Y.; Wang, L.-F.; Shi, Z. Serological evidence of ebolavirus infection in bats, China. Virol. J. 2012, 9, 236. [CrossRef] [PubMed]

25. Formenty, P.; Hatz, C.; Le Guenno, B.; Stoll, A.; Rogenmoser, P.; Widmer, A. Human infection due to Ebola virus, subtype Côte d'Ivoire: Clinical and biologic presentation. J. Infect. Dis. 1999, 179 (Suppl. 1), S48-S53. [CrossRef]

26. Geisbert, T.W.; Jahrling, P.B. Differentiation of filoviruses by electron microscopy. Virus Res. 1995, 39, $129-150$. [CrossRef]

27. Emanuel, J.; Marzi, A.; Feldmann, H. Filoviruses: Ecology, molecular biology, and evolution. Adv. Virus Res. 2018, 100, 189-221.

28. Mühlberger, E. Filovirus replication and transcription. Future Virol. 2007, 2, 205-215. [CrossRef]

29. Neumann, G.; Watanabe, S.; Kawaoka, Y. Characterization of Ebolavirus regulatory Genomic regions. Virus Res. 2009, 144, 1-7. [CrossRef]

30. Hofmann-Winkler, H.; Kaup, F.; Pöhlmann, S. Host cell factors in Filovirus entry: Novel players, new insights. Viruses 2012, 4, 3336-3362. [CrossRef]

31. Groseth, A.; Marzi, A.; Hoenen, T.; Herwig, A.; Gardner, D.; Becker, S.; Ebihara, H.; Feldmann, H. The Ebola virus glycoprotein contributes to but is not sufficient for virulence in vivo. PLoS. Pathog. 2012, 8. [CrossRef]

32. Leroy, E.M.; Kumulungui, B.; Pourrut, X.; Rouquet, P.; Hassanin, A.; Yaba, P.; Délicat, A.; Paweska, J.T.; Gonzalez, J.-P.; Swanepoel, R. Fruit bats as reservoirs of Ebola virus. Nature 2005, 438, 575-576. [CrossRef]

33. Vetter, P.; Fischer, W.A.; Schibler, M.; Jacobs, M.; Bausch, D.G.; Kaiser, L. Ebola virus shedding and transmission: Review of current evidence. J. Infect. Dis. 2016, 214, S177-S184. [CrossRef]

34. Eichner, M.; Dowell, S.F.; Firese, N. Incubation period of Ebola hemorrhagic virus subtype Zaire. Osong. Public Health Res. Perspect. 2011, 2, 3-7. [CrossRef]

35. Breman, J.G.; Heymann, D.L.; Lloyd, G.; McCormick, J.B.; Miatudila, M.; Murphy, F.A.; Muyembé-Tamfun, J.-J.; Piot, P.; Ruppol, J.-F.; Sureau, P.; et al. Discovery and description of Ebola Zaire virus in 1976 and relevance to the West African epidemic during 2013-2016. J. Infect. Dis. 2016, 214, S93-S101. [CrossRef] [PubMed]

36. Bwaka, M.A.; Bonnet, M.J.; Calain, P.; Colebunders, R.; De Roo, A.; Guimard, Y.; Katwiki, K.R.; Kibadi, K.; Kipasa, M.A.; Kuvula, K.J.; et al. Ebola hemorrhagic fever in Kikwit, Democratic Republic of the Congo: Clinical observations in 103 patients. J. Infect. Dis. 1999, 179 (Suppl. 1), S1-S7. [CrossRef]

37. Lekone, P.E.; Finkenstädt, B.F. Statistical inference in a stochastic epidemic SEIR model with control intervention: Ebola as a case study. Biometrics 2006, 62, 1170-1177. [CrossRef] [PubMed]

38. Martini, G.A.; Siegert, R. Marburg Virus Disease; Springer: New York, NY, USA, 1971; pp. 166-176.

39. Slenczka, W.G. The Marburg virus outbreak of 1967 and subsequent episodes. Curr. Top. Microbiol. Immunol. 1999, 235, 49-75. [CrossRef]

40. Van Kerkhove, M.D.; Bento, A.I.; Mills, H.L.; Ferguson, N.M.; Donnelly, C.A. A review of epidemiological parameters from Ebola outbreaks to inform early public health decision-making. Sci. Data 2015, 2, 150019. [CrossRef] [PubMed]

41. Hoenen, T.; Groseth, A.; Falzarano, D.; Feldmann, H. Ebola virus: Unravelling pathogenesis to combat a deadly disease. Trends. Mol. Med. 2006, 12, 206-215. [CrossRef]

42. Geisbert, T.W.; Jaax, N.K. Marburg hemorrhagic fever: Report of a case studied by immunohistochemistry and electron microscopy. Ultrastruct. Pathol. 1998, 22, 3-17. [CrossRef]

43. Mehedi, M.; Groseth, A.; Feldmann, H.; Ebihara, H. Clinical aspects of Marburg hemorrhagic fever. Future Virol. 2011, 6, 1091-1106. [CrossRef]

44. Gautier, E.L.; Jakubzick, C.; Randolph, G.J. Regulation of the migration and survival of monocyte subsets by chemokine receptors and its relevance to atherosclerosis. Arterioscler. Thromb. Vasc. Biol. 2009, 29, 1412-1418. [CrossRef] [PubMed]

45. Morris, D.L.; Singer, K.; Lumeng, C.N. Adipose tissue macrophages: Phenotypic plasticity and diversity in lean and obese states. Curr. Opin. Clin. Nutr. Metab. Care 2011, 14, 341-346. [CrossRef] 
46. Robinson, M.J.; Sancho, D.; Slack, E.C.; LeibundGut-Landmann, S.; Sousa, C.R.E. Myeloid C-type lectins in innate immunity. Nat. Immunol. 2006, 7, 1258-1265. [CrossRef]

47. Shabo, I.; Svanvik, J. Expression of macrophage antigens by tumor cells. Adv. Exp. Med. Biol. 2011, 714, 141-150. [CrossRef]

48. Bosio, C.M.; Aman, M.J.; Grogan, C.; Hogan, R.; Ruthel, G.; Negley, D.; Mohamadzadeh, M.; Bavari, S.; Schmaljohn, A. Ebola and Marburg viruses replicate in monocyte-derived dendritic cells without inducing the production of cytokines and full maturation. J. Infect. Dis. 2003, 188, 1630-1638. [CrossRef]

49. Lubaki, N.M.; Ilinykh, P.; Pietzsch, C.; Tigabu, B.; Freiberg, A.N.; Koup, R.A.; Bukreyev, A. The lack of maturation of Ebola virus-infected dendritic cells results from the cooperative effect of at least two viral domains. J. Virol. 2013, 87, 7471-7485. [CrossRef]

50. Geisbert, T.W.; Hensley, L.E.; Gibb, T.R.; Steele, K.E.; Jaax, N.K.; Jahrling, P.B. Apoptosis induced in vitro and in vivo during infection by Ebola and Marburg viruses. Lab. Invest. 2000, 80, 171-186. [CrossRef]

51. Bradfute, S.B.; Braun, D.R.; Shamblin, J.D.; Geisbert, J.B.; Paragas, J.; Garrison, A.; Hensley, L.E.; Geisbert, T.W. Lymphocyte death in a mouse model of Ebola virus infection. J. Infect. Dis. 2007, 196, S296-S304. [CrossRef] [PubMed]

52. Gupta, M.; Spiropoulou, C.; Rollin, P.E. Ebola virus infection of human PBMCs causes massive death of macrophages, CD4 and CD8 T cell sub-populations in vitro. Virology 2007, 364, 45-54. [CrossRef]

53. Baize, S.; Leroy, E.M.; Georges-Courbot, M.C.; Capron, M.; Lansoud-Soukate, J.; Debré, P.; Fisher-Hoch, S.P.; McCormick, J.B.; Georges, A.J. Defective humoral responses and extensive intravascular apoptosis are associated with fatal outcome in Ebola virus-infected patients. Nat. Med. 1999, 5, 423-426. [CrossRef]

54. McElroy, A.K.; Akondy, R.S.; Davis, C.W.; Ellebedy, A.H.; Mehta, A.K.; Kraft, C.S.; Lyon, G.M.; Ribner, B.S.; Varkey, J.; Sidney, J.; et al. Human Ebola virus infection results in substantial immune activation. Proc. Natl. Acad. Sci. USA 2015, 112, 4719-4724. [CrossRef]

55. Schindell, B.G.; Webb, A.L.; Kindrachuk, J. Persistence and sexual transmission of Filoviruses. Viruses 2018, 10, 683. [CrossRef]

56. Lupton, H.W.; Lambert, R.D.; Bumgardner, D.L.; Moe, J.B.; Eddy, G.A. Inactivated vaccine for Ebola virus efficacious in guineapig model. Lancet 1980, 2, 1294-1295. [CrossRef]

57. Reynolds, P.; Marzi, A. Ebola and Marburg virus vaccines. Virus Genes. 2017, 53, 501-515. [CrossRef] [PubMed]

58. Heald, A.E.; Charleston, J.S.; Iversen, P.L.; Warren, T.K.; Saoud, J.B.; Al-Ibrahim, M.; Wells, J.; Warfield, K.L.; Swenson, D.L.; Welch, L.S.; et al. AVI-7288 for Marburg virus in nonhuman primates and humans. N. Engl. J. Med. 2015, 373, 339-348. [CrossRef]

59. Sarwar, U.N.; Costner, P.; Enama, M.E.; Berkowitz, N.; Hu, Z.; Hendel, C.S.; Sitar, S.; Plummer, S.; Mulangu, S.; Bailer, R.T.; et al. Safety and immunogenicity of DNA vaccines encoding Ebolavirus and Marburgvirus wild-type glycoproteins in a phase I clinical trial. J. Infect. Dis. 2015, 211, 549-557. [CrossRef] [PubMed]

60. Kibuuka, H.; Berkowitz, N.M.; Millard, M.; Enama, M.E.; Tindikahwa, A.; Sekiziyivu, A.B.; Costner, P.; Sitar, S.; Glover, D.; Hu, Z.; et al. Safety and immunogenicity of Ebola virus and Marburg virus glycoprotein DNA vaccines assessed separately and concomitantly in healthy Ugandan adults: A phase 1b, randomised, double-blind, placebo-controlled clinical trial. Lancet 2015, 385, 1545-1554. [CrossRef]

61. Henao-Restrepo, A.M.; Camacho, A.; Longini, I.M.; Watson, C.H.; Edmunds, W.J.; Egger, M.; Carroll, M.W.; Dean, N.E.; Diatta, I.; Doumbia, M.; et al. Efficacy and effectiveness of an rVSV-vectored vaccine in preventing Ebola virus disease: Final results from the Guinea ring vaccination, open-label, cluster-randomised trial (Ebola Ça Suffit!). Lancet 2017, 389, 505-518. [CrossRef]

62. Mupapa, K.; Massamba, M.; Kibadi, K.; Kuvula, K.; Bwaka, A.; Kipasa, M.; Colebunders, R.; Muyembe-Tamfum, J.J. Treatment of Ebola hemorrhagic fever with blood transfusions from convalescent patients. J. Infect. Dis. 1999, 179, S18-S23. [CrossRef]

63. Siragam, V.; Wong, G.; Qiu, X.-G. Animal models for filovirus infections. Zool. Res. 2018, 39, 15-24. [CrossRef]

64. Kozak, R.; He, S.; Kroeker, A.; de La Vega, M.-A.; Audet, J.; Wong, G.; Urfano, C.; Antonation, K.; Embury-Hyatt, C.; Kobinger, G.P.; et al. Ferrets infected with Bundibugyo virus or Ebola virus recapitulate important aspects of human Filovirus disease. J. Virol. 2016, 90, 9209-9223. [CrossRef]

65. Gibb, T.R.; Bray, M.; Geisbert, T.W.; Steele, K.E.; Kell, W.M.; Davis, K.J.; Jaax, N.K. Pathogenesis of experimental Ebola Zaire virus infection in BALB/c mice. J. Comp. Pathol. 2001, 125, 233-242. [CrossRef] [PubMed] 
66. Qiu, X.; Fernando, L.; Melito, P.L.; Audet, J.; Feldmann, H.; Kobinger, G.; Alimonti, J.B.; Jones, S.M. Ebola GP-specific monoclonal antibodies protect mice and guinea pigs from lethal Ebola virus infection. PLoS. Negl. Trop. Dis. 2012, 6, e1575. [CrossRef]

67. Pascal, K.E.; Dudgeon, D.; Trefry, J.C.; Anantpadma, M.; Sakurai, Y.; Murin, C.D.; Turner, H.L.; Fairhurst, J.; Torres, M.; Rafique, A.; et al. Development of clinical-stage human monoclonal antibodies that treat advanced Ebola virus disease in nonhuman primates. J. Infect. Dis. 2018, 218, S612-S626. [CrossRef] [PubMed]

68. Banadyga, L.; Wong, G.; Qiu, X. Small animal models for evaluating Filovirus countermeasures. ACS. Infect. Dis. 2018, 4, 673-685. [CrossRef] [PubMed]

69. Dye, J.M.; Herbert, A.S.; Kuehne, A.I.; Barth, J.F.; Muhammad, M.A.; Zak, S.E.; Ortiz, R.A.; Prugar, L.I.; Pratt, W.D. Postexposure antibody prophylaxis protects nonhuman primates from filovirus disease. Proc. Natl. Acad. Sci. USA 2012, 109, 5034-5039. [CrossRef]

70. Marzi, A.; Yoshida, R.; Miyamoto, H.; Ishijima, M.; Suzuki, Y.; Higuchi, M.; Matsuyama, Y.; Igarashi, M.; Nakayama, E.; Kuroda, M.; et al. Protective efficacy of neutralizing monoclonal antibodies in a nonhuman primate model of Ebola hemorrhagic fever. PLoS ONE 2012, 7, e36192. [CrossRef]

71. Olinger, G.G.; Pettitt, J.; Kim, D.; Working, C.; Bohorov, O.; Bratcher, B.; Hiatt, E.; Hume, S.D.; Johnson, A.K.; Morton, J.; et al. Delayed treatment of Ebola virus infection with plant-derived monoclonal antibodies provides protection in rhesus macaques. Proc. Natl. Acad. Sci. USA 2012, 109, 18030-18035. [CrossRef]

72. Pettitt, J.; Zeitlin, L.; Kim, D.H.; Working, C.; Johnson, J.C.; Bohorov, O.; Bratcher, B.; Hiatt, E.; Hume, S.D.; Johnson, A.K.; et al. Therapeutic intervention of Ebola virus infection in rhesus macaques with the MB-003 monoclonal antibody cocktail. Sci. Transl. Med. 2013, 5, 199ra113. [CrossRef]

73. Marzi, A.; Engelmann, F.; Feldmann, F.; Haberthur, K.; Shupert, W.L.; Brining, D.; Scott, D.P.; Geisbert, T.W.; Kawaoka, Y.; Katze, M.G.; et al. Antibodies are necessary for rVSV/ZEBOV-GP-mediated protection against lethal Ebola virus challenge in nonhuman primates. Proc. Natl. Acad. Sci. USA 2013, 110, 1893-1898. [CrossRef]

74. Wong, G.; Richardson, J.S.; Pillet, S.; Patel, A.; Qiu, X.; Alimonti, J.; Hogan, J.; Zhang, Y.; Takada, A.; Feldmann, H.; et al. Immune parameters correlate with protection against Ebola virus infection in rodents and nonhuman primates. Sci. Transl. Med. 2012, 4, 158ra146. [CrossRef]

75. Qiu, X.; Alimonti, J.B.; Melito, P.L.; Fernando, L.; Ströher, U.; Jones, S.M. Characterization of Zaire ebolavirus glycoprotein-specific monoclonal antibodies. J. Clin. Immunol. 2011, 141, 218-227. [CrossRef]

76. Martinez, O.; Tantral, L.; Mulherkar, N.; Chandran, K.; Basler, C.F. Impact of Ebola mucin-like domain on antiglycoprotein antibody responses induced by Ebola virus-like particles. J. Infect. Dis. 2011, 204, S825-S832. [CrossRef]

77. Murin, C.D.; Fusco, M.L.; Bornholdt, Z.A.; Qiu, X.; Olinger, G.G.; Zeitlin, L.; Kobinger, G.P.; Ward, A.B.; Saphire, E.O. Structures of protective antibodies reveal sites of vulnerability on Ebola virus. Proc. Natl. Acad. Sci. USA 2014, 111, 17182-17187. [CrossRef]

78. Qiu, X.; Audet, J.; Wong, G.; Pillet, S.; Bello, A.; Cabral, T.; Strong, J.E.; Plummer, F.; Corbett, C.R.; Alimonti, J.B.; et al. Successful treatment of ebola virus-infected cynomolgus macaques with monoclonal antibodies. Sci. Transl. Med. 2012, 4, 138ra81. [CrossRef]

79. Davison, E.; Bryan, C.; Fong, R.H.; Barnes, T.; Pfaff, J.M.; Mabila, M.; Rucker, J.B.; Doranz, B.J. Mechanism of binding to Ebola virus glycoprotein by the ZMapp, ZMAb, and MB-003 cocktail antibodies. J. Virol. 2015, 89, 10982-10992. [CrossRef]

80. Budzianowski, J. Tobacco against Ebola virus disease. Prz. Lek. 2015, 72, 567-571.

81. Wilson, J.A.; Hevey, M.; Bakken, R.; Guest, S.; Bray, M.; Schmaljohn, A.L.; Hart, M.K. Epitopes involved in antibody-mediated protection from Ebola Virus. Science 2000, 287, 1664-1666. [CrossRef]

82. Qiu, X.; Wong, G.; Audet, J.; Bello, A.; Fernando, L.; Alimonti, J.B.; Fausther-Bovendo, H.; Wei, H.; Aviles, J.; Hiatt, E.; et al. Reversion of advanced Ebola virus disease in nonhuman primates with ZMapp ${ }^{\mathrm{TM}}$. Nature 2014, 514, 47-53. [CrossRef]

83. Group, The PREVAIL II Writing Group for the Multi-National PREVAIL II Study Team. A Randomized, Controlled Trial of ZMapp for Ebola Virus Infection. New Engl. J. Med. 2016, 375, 1448-1456. [CrossRef] [PubMed]

84. LoBuglio, A.F.; Wheeler, R.H.; Trang, J.; Haynes, A.; Rogers, K.; Harvey, E.B.; Sun, L.; Ghrayeb, J.; Khazaeli, M.B. Mouse/human chimeric monoclonal antibody in man: Kinetics and immune response. Proc. Natl. Acad. Sci. USA 1989, 86, 4220-4224. [CrossRef] 
85. Lu, R.-M.; Hwang, Y.-C.; Liu, I.-J.; Lee, C.-C.; Tsai, H.-Z.; Li, H.-J.; Wu, H.-C. Development of therapeutic antibodies for the treatment of diseases. J. Biomed. Sci. 2020, 27, 1. [CrossRef] [PubMed]

86. Harding, F.A.; Stickler, M.M.; Razo, J.; DuBridge, R.B. The immunogenicity of humanized and fully human antibodies. MAbs 2010, 2, 256-265. [CrossRef]

87. Hwang, W.Y.K.; Foote, J. Immunogenicity of engineered antibodies. Methods 2005, 36, 3-10. [CrossRef]

88. Weiner, L.M.; Surana, R.; Wang, S. Monoclonal antibodies: Versatile platforms for cancer immunotherapy. Nat. Rev. Immunol. 2010, 10, 317-327. [CrossRef]

89. Bruhns, P.; Jönsson, F. Mouse and human FcR effector functions. Immunol. Rev. 2015, 268, 25-51. [CrossRef]

90. Corti, D.; Misasi, J.; Mulangu, S.; Stanley, D.A.; Kanekiyo, M.; Wollen, S.; Ploquin, A.; Doria-Rose, N.A.; Staupe, R.P.; Bailey, M.; et al. Protective monotherapy against lethal Ebola virus infection by a potently neutralizing antibody. Science 2016, 351, 1339-1342. [CrossRef] [PubMed]

91. Gilchuk, P.; Mire, C.E.; Geisbert, J.B.; Agans, K.N.; Deer, D.J.; Cross, R.W.; Slaughter, J.C.; Flyak, A.I.; Mani, J.; Pauly, M.H.; et al. Efficacy of human monoclonal antibody monotherapy against Bundibugyo virus infection in nonhuman primates. J. Infect. Dis. 2018, 218, S565-S573. [CrossRef]

92. Muyembe-Tamfum, J.J.; Kipasa, M.; Kiyungu, C.; Colebunders, R. Ebola outbreak in Kikwit, Democratic Republic of the Congo: Discovery and control measures. J. Infect. Dis. 1999, 179 (Suppl. 1), S259-S262. [CrossRef]

93. Gaudinski, M.R.; Coates, E.E.; Novik, L.; Widge, A.; Houser, K.V.; Burch, E.; Holman, L.A.; Gordon, I.J.; Chen, G.L.; Carter, C.; et al. Safety, tolerability, pharmacokinetics, and immunogenicity of mAb114: A phase 1 trial of a therapeutic monoclonal antibody targeting Ebola virus glycoprotein. Lancet 2019, 393, 889-898. [CrossRef]

94. Mire, C.E.; Geisbert, J.B.; Borisevich, V.; Fenton, K.A.; Agans, K.N.; Flyak, A.I.; Deer, D.J.; Steinkellner, H.; Bohorov, O.; Bohorova, N.; et al. Therapeutic treatment of Marburg and Ravn virus infection in nonhuman primates with a human monoclonal antibody. Sci. Transl. Med. 2017, 9. [CrossRef]

95. Flyak, A.I.; Ilinykh, P.A.; Murin, C.D.; Garron, T.; Shen, X.; Fusco, M.L.; Hashiguchi, T.; Bornholdt, Z.A.; Slaughter, J.C.; Sapparapu, G.; et al. Mechanism of human antibody-mediated neutralization of Marburg virus. Cell 2015, 160, 893-903. [CrossRef]

96. Ledgerwood, J.E.; DeZure, A.D.; Stanley, D.A.; Coates, E.E.; Novik, L.; Enama, M.E.; Berkowitz, N.M.; Hu, Z.; Joshi, G.; Ploquin, A.; et al. Chimpanzee adenovirus vector Ebola vaccine. N. Engl. J. Med. 2017, 376, 928-938. [CrossRef]

97. Fusco, M.L.; Hashiguchi, T.; Cassan, R.; Biggins, J.E.; Murin, C.D.; Warfield, K.L.; Li, S.; Holtsberg, F.W.; Shulenin, S.; Vu, H.; et al. Protective $\mathrm{mAbs}$ and cross-reactive $\mathrm{mAbs}$ raised by immunization with engineered Marburg virus GPs. PLoS. Pathog. 2015, 11, e1005016. [CrossRef]

98. Brannan, J.M.; He, S.; Howell, K.A.; Prugar, L.I.; Zhu, W.; Vu, H.; Shulenin, S.; Kailasan, S.; Raina, H.; Wong, G.; et al. Post-exposure immunotherapy for two ebolaviruses and Marburg virus in nonhuman primates. Nat. Commun. 2019, 10. [CrossRef]

99. Holtsberg, F.W.; Shulenin, S.; Vu, H.; Howell, K.A.; Patel, S.J.; Gunn, B.; Karim, M.; Lai, J.R.; Frei, J.C.; Nyakatura, E.K.; et al. Pan-ebolavirus and pan-filovirus mouse monoclonal antibodies: Protection against Ebola and Sudan viruses. J. Virol. 2016, 90, 266-278. [CrossRef] [PubMed]

100. Zhao, X.; Howell, K.A.; He, S.; Brannan, J.M.; Wec, A.Z.; Davidson, E.; Turner, H.L.; Chiang, C.-I.; Lei, L.; Fels, J.M.; et al. Immunization-elicited broadly protective antibody reveals Ebolavirus fusion loop as a site of vulnerability. Cell 2017, 169, 891-904. [CrossRef]

101. Howell, K.A.; Qiu, X.; Brannan, J.M.; Bryan, C.; Davidson, E.; Holtsberg, F.W.; Wec, A.Z.; Shulenin, S.; Biggins, J.E.; Douglas, R.; et al. Antibody treatment of Ebola and Sudan virus infection via a uniquely exposed epitope within the glycoprotein receptor-binding site. Cell. Rep. 2016, 15, 1514-1526. [CrossRef]

102. Bornholdt, Z.A.; Turner, H.L.; Murin, C.D.; Li, W.; Sok, D.; Souders, C.A.; Piper, A.E.; Goff, A.; Shamblin, J.D.; Wollen, S.E.; et al. Isolation of potent neutralizing antibodies from a survivor of the 2014 Ebola virus outbreak. Science 2016, 351, 1078-1083. [CrossRef]

103. Wec, A.Z.; Herbert, A.S.; Murin, C.D.; Nyakatura, E.K.; Abelson, D.M.; Fels, J.M.; He, S.; James, R.M.; de La Vega, M.-A.; Zhu, W.; et al. Antibodies from a human survivor define sites of vulnerability for broad protection against Ebolaviruses. Cell 2017, 169, 878-890. [CrossRef] 
104. Flyak, A.I.; Shen, X.; Murin, C.D.; Turner, H.L.; David, J.A.; Fusco, M.L.; Lampley, R.; Kose, N.; Ilinykh, P.A.; Kuzmina, N.; et al. Cross-reactive and potent neutralizing antibody responses in human survivors of natural Ebola virus infection. Cell 2016, 164, 392-405. [CrossRef]

105. King, L.B.; West, B.R.; Moyer, C.L.; Gilchuk, P.; Flyak, A.; Ilinykh, P.A.; Bombardi, R.; Hui, S.; Huang, K.; Bukreyev, A.; et al. Cross-reactive neutralizing human survivor monoclonal antibody BDBV223 targets the ebolavirus stalk. Nat. Commun. 2019, 10, 1788. [CrossRef]

106. Flyak, A.I.; Kuzmina, N.; Murin, C.D.; Bryan, C.; Davidson, E.; Gilchuk, P.; Gulka, C.P.; Ilinykh, P.A.; Shen, X.; Huang, K.; et al. Broadly neutralizing antibodies from human survivors target a conserved site in the Ebola virus glycoprotein HR2/MPER region. Nat. Microbiol. 2018, 3, 670-677. [CrossRef]

107. Keck, Z.-Y.; Enterlein, S.G.; Howell, K.A.; Vu, H.; Shulenin, S.; Warfield, K.L.; Froude, J.W.; Araghi, N.; Douglas, R.; Biggins, J.; et al. Macaque monoclonal antibodies targeting novel conserved epitopes within Filovirus glycoprotein. J. Virol. 2015, 90, 279-291. [CrossRef] [PubMed]

108. Wec, A.Z.; Bornholdt, Z.A.; He, S.; Herbert, A.S.; Goodwin, E.; Wirchnianski, A.S.; Gunn, B.M.; Zhang, Z.; Zhu, W.; Liu, G.; et al. Development of a human antibody cocktail that deploys multiple functions to confer pan-Ebolavirus protection. Cell Host Microbe. 2019, 25, 39-48. [CrossRef]

109. Russell, S.; Bennett, J.; Wellman, J.A.; Chung, D.C.; Yu, Z.-F.; Tillman, A.; Wittes, J.; Pappas, J.; Elci, O.; McCague, S.; et al. Efficacy and safety of voretigene neparvovec (AAV2-hRPE65v2) in patients with RPE65-mediated inherited retinal dystrophy: A randomised, controlled, open-label, phase 3 trial. Lancet 2017, 390, 849-860. [CrossRef]

110. Mendell, J.R.; Al-Zaidy, S.; Shell, R.; Arnold, W.D.; Rodino-Klapac, L.R.; Prior, T.W.; Lowes, L.; Alfano, L.; Berry, K.; Church, K.; et al. Single-dose gene-replacement therapy for spinal muscular atrophy. N. Engl. J. Med. 2017, 377, 1713-1722. [CrossRef]

111. Daya, S.; Berns, K.I. Gene therapy using adeno-associated virus vectors. Clin. Microbiol. Rev. 2008, 21, 583-593. [CrossRef]

112. Penaud-Budloo, M.; Le Guiner, C.; Nowrouzi, A.; Toromanoff, A.; Chérel, Y.; Chenuaud, P.; Schmidt, M.; von Kalle, C.; Rolling, F.; Moullier, P.; et al. Adeno-associated virus vector genomes persist as episomal chromatin in primate muscle. J. Virol. 2008, 82, 7875-7885. [CrossRef] [PubMed]

113. Toromanoff, A.; Chérel, Y.; Guilbaud, M.; Penaud-Budloo, M.; Snyder, R.O.; Haskins, M.E.; Deschamps, J.-Y.; Guigand, L.; Podevin, G.; Arruda, V.R.; et al. Safety and efficacy of regional intravenous (RI) versus intramuscular (IM) delivery of rAAV1 and rAAV8 to nonhuman primate skeletal muscle. Mol. Ther. 2008, 16, 1291-1299. [CrossRef]

114. Balazs, A.B.; Chen, J.; Hong, C.M.; Rao, D.S.; Yang, L.; Baltimore, D. Antibody-based protection against HIV infection by vectored immunoprophylaxis. Nature 2011, 481, 81-84. [CrossRef]

115. Chng, J.; Wang, T.; Nian, R.; Lau, A.; Hoi, K.M.; Ho, S.C.; Gagnon, P.; Bi, X.; Yang, Y. Cleavage efficient 2A peptides for high level monoclonal antibody expression in CHO cells. MAbs 2015, 7, 403-412. [CrossRef]

116. Van Lieshout, L.P.; Soule, G.; Sorensen, D.; Frost, K.L.; He, S.; Tierney, K.; Safronetz, D.; Booth, S.A.; Kobinger, G.P.; Qiu, X.; et al. Intramuscular adeno-associated virus-mediated expression of monoclonal antibodies provides 100\% protection against Ebola virus infection in mice. J. Infect. Dis. 2018, 217, 916-925. [CrossRef]

117. Balazs, A.B.; Ouyang, Y.; Hong, C.M.; Chen, J.; Nguyen, S.M.; Rao, D.S.; An, D.S.; Baltimore, D. Vectored immunoprophylaxis protects humanized mice from mucosal HIV transmission. Nat. Med. 2014, 20, $296-300$. [CrossRef] [PubMed]

118. Johnson, P.R.; Schnepp, B.C.; Zhang, J.; Connell, M.J.; Greene, S.M.; Yuste, E.; Desrosiers, R.C.; Clark, K.R. Vector-mediated gene transfer engenders long-lived neutralizing activity and protection against SIV infection in monkeys. Nat. Med. 2009, 15, 901-906. [CrossRef]

119. Martinez-Navio, J.M.; Fuchs, S.P.; Pantry, S.N.; Lauer, W.A.; Duggan, N.N.; Keele, B.F.; Rakasz, E.G.; Gao, G.; Lifson, J.D.; Desrosiers, R.C. Adeno-associated virus delivery of anti-HIV monoclonal antibodies can drive long-term virologic suppression. Immunity 2019, 50, 567-575. [CrossRef]

120. Fuchs, S.P.; Martinez-Navio, J.M.; Piatak , M., Jr.; Lifson, J.D.; Gao, G.; Desrosiers, R.C. AAV-Delivered antibody mediates significant protective effects against SIVmac239 challenge in the absence of neutralizing activity. PLoS. Pathog. 2015, 11, e1005090. [CrossRef] [PubMed]

121. Balazs, A.B.; Bloom, J.D.; Hong, C.M.; Rao, D.S.; Baltimore, D. Broad protection against influenza infection by vectored immunoprophylaxis in mice. Nat. Biotechnol. 2013, 31, 647-652. [CrossRef] 
122. Deal, C.; Balazs, A.B.; Espinosa, D.A.; Zavala, F.; Baltimore, D.; Ketner, G. Vectored antibody gene delivery protects against Plasmodium falciparum sporozoite challenge in mice. Proc. Natl. Acad. Sci. USA 2014, 111, 12528-12532. [CrossRef]

123. De Jong, Y.P.; Dorner, M.; Mommersteeg, M.C.; Xiao, J.W.; Balazs, A.B.; Robbins, J.B.; Winer, B.Y.; Gerges, S.; Vega, K.; Labitt, R.N.; et al. Broadly neutralizing antibodies abrogate established hepatitis $C$ virus infection. Sci. Transl. Med. 2014, 6, 254ra129. [CrossRef]

124. Priddy, F.H.; Lewis, D.J.M.; Gelderblom, H.C.; Hassanin, H.; Streatfield, C.; LaBranche, C.; Hare, J.; Cox, J.H.; Dally, L.; Bendel, D.; et al. Adeno-associated virus vectored immunoprophylaxis to prevent HIV in healthy adults: A phase 1 randomised controlled trial. Lancet HIV 2019, 6, e230-e239. [CrossRef]

125. Lewis, A.D.; Chen, R.; Montefiori, D.C.; Johnson, P.R.; Clark, K.R. Generation of neutralizing activity against human immunodeficiency virus type 1 in serum by antibody gene transfer. J. Virol. 2002, 76, 8769-8775. [CrossRef]

126. Limberis, M.P.; Adam, V.S.; Wong, G.; Gren, J.; Kobasa, D.; Ross, T.M.; Kobinger, G.P.; Tretiakova, A.; Wilson, J.M. Intranasal antibody gene transfer in mice and ferrets elicits broad protection against pandemic influenza. Sci. Transl. Med. 2013, 5, 187ra72. [CrossRef]

127. Limberis, M.P.; Tretiakova, A.; Nambiar, K.; Wong, G.; Racine, T.; Crosariol, M.; Xiangguo, Q.; Kobinger, G.; Wilson, J.M. Adeno-associated virus serotype 9-expressed ZMapp in mice confers protection against systemic and airway-acquired Ebola virus infection. J. Infect. Dis. 2016, 214, 1975-1979. [CrossRef]

128. Robert, M.-A.; Nassoury, N.; Chahal, P.S.; Venne, M.-H.; Racine, T.; Qiu, X.; Kobinger, G.; Kamen, A.; Gilbert, R.; Gaillet, B. Gene transfer of ZMapp antibodies mediated by recombinant adeno-associated virus protects against Ebola infections. Hum. Gene Ther. 2017, 29, 452-466. [CrossRef]

129. Flotte, T.R.; Trapnell, B.C.; Humphries, M.; Carey, B.; Calcedo, R.; Rouhani, F.; Campbell-Thompson, M.; Yachnis, A.T.; Sandhaus, R.A.; McElvaney, N.G.; et al. Phase 2 clinical trial of a recombinant adeno-associated viral vector expressing $\alpha 1$-antitrypsin: Interim results. Hum. Gene Ther. 2011, 22, 1239-1247. [CrossRef]

130. Weber, A.; Engelmaier, A.; Voelkel, D.; Pachlinger, R.; Scheiflinger, F.; Monahan, P.E.; Rottensteiner, H. Development of methods for the selective measurement of the single amino acid exchange variant coagulation factor IX Padua. Mol. Ther. Methods Clin. Dev. 2018, 10, 29-37. [CrossRef] [PubMed]

131. Miesbach, W.; Meijer, K.; Coppens, M.; Kampmann, P.; Klamroth, R.; Schutgens, R.; Tangelder, M.; Castaman, G.; Schwäble, J.; Bonig, H.; et al. Gene therapy with adeno-associated virus vector 5-human factor IX in adults with hemophilia B. Blood 2018, 131, 1022-1031. [CrossRef]

132. Martinez-Navio, J.M.; Fuchs, S.P.; Mendes, D.E.; Rakasz, E.G.; Gao, G.; Lifson, J.D.; Desrosiers, R.C. Long-term delivery of an anti-SIV monoclonal antibody with AAV. Front. Immunol. 2020, 11. [CrossRef]

133. Van Lieshout, L.P.; Domm, J.M.; Rindler, T.N.; Frost, K.L.; Sorensen, D.L.; Medina, S.J.; Booth, S.A.; Bridges, J.P.; Wootton, S.K. A novel triple-mutant AAV6 capsid induces rapid and potent transgene expression in the muscle and respiratory tract of mice. Mol. Ther. Methods Clin. Dev. 2018, 9, 323-329. [CrossRef]

134. Croyle, M.A.; Cheng, X.; Wilson, J.M. Development of formulations that enhance physical stability of viral vectors for gene therapy. Gene Ther. 2001, 8, 1281-1290. [CrossRef]

135. Martinez-Navio, J.M.; Fuchs, S.P.; Pedreño-López, S.; Rakasz, E.G.; Gao, G.; Desrosiers, R.C. Host anti-antibody responses following adeno-associated virus-mediated delivery of antibodies against HIV and SIV in rhesus monkeys. Mol. Ther. 2016, 24, 76-86. [CrossRef]

136. Saunders, K.O.; Wang, L.; Joyce, M.G.; Yang, Z.Y.; Balazs, A.B.; Cheng, C.; Ko, S.-Y.; Kong, W.-P.; Rudicell, R.S.; Georgiev, I.S.; et al. Broadly neutralizing human immunodeficiency virus type 1 antibody gene transfer protects nonhuman primates from mucosal simian-human immunodeficiency virus infection. J. Virol. 2015, 89, 8334-8345. [CrossRef]

137. Scharf, L.; West, A.P.; Sievers, S.A.; Chen, C.; Jiang, S.; Gao, H.; Gray, M.D.; McGuire, A.T.; Scheid, J.F.; Nussenzweig, M.C.; et al. Structural basis for germline antibody recognition of HIV-1 immunogens. eLife 2016, 5. [CrossRef]

138. Wu, X.; Zhou, T.; Zhu, J.; Zhang, B.; Georgiev, I.; Wang, C.; Chen, X.; Longo, N.S.; Louder, M.; McKee, K.; et al. Focused evolution of HIV-1 neutralizing antibodies revealed by structures and deep sequencing. Science 2011, 333, 1593-1602. [CrossRef]

139. Kwong, P.D.; Mascola, J.R. Human antibodies that neutralize HIV-1: Identification, structures, and B cell ontogenies. Immunity 2012, 37, 412-425. [CrossRef] 
140. Moody, M.A.; Zhang, R.; Walter, E.B.; Woods, C.W.; Ginsburg, G.S.; McClain, M.T.; Denny, T.N.; Chen, X.; Munshaw, S.; Marshall, D.J.; et al. H3N2 influenza infection elicits more cross-reactive and less clonally expanded anti-hemagglutinin antibodies than influenza vaccination. PLoS ONE 2011, 6, e25797. [CrossRef]

141. Kalinke, U.; Bucher, E.M.; Ernst, B.; Oxenius, A.; Roost, H.P.; Geley, S.; Kofler, R.; Zinkernagel, R.M.; Hengartner, $\mathrm{H}$. The role of somatic mutation in the generation of the protective humoral immune response against vesicular stomatitis virus. Immunity 1996, 5, 639-652. [CrossRef]

142. Walker, L.M.; Phogat, S.K.; Chan-Hui, P.-Y.; Wagner, D.; Phung, P.; Goss, J.L.; Wrin, T.; Simek, M.D.; Fling, S.; Mitcham, J.L.; et al. Broad and potent neutralizing antibodies from an African donor reveal a new HIV-1 vaccine target. Science 2009, 326, 285-289. [CrossRef]

143. Shcherbakov, D.N.; Bakulina, A.Y.; Karpenko, L.I.; Ilyichev, A.A. Broadly neutralizing antibodies against HIV-1 as a novel aspect of the immune response. Acta Nat. 2015, 7, 11-21. [CrossRef]

144. Huang, J.; Ofek, G.; Laub, L.; Louder, M.K.; Doria-Rose, N.A.; Longo, N.S.; Imamichi, H.; Bailer, R.T.; Chakrabarti, B.; Sharma, S.K.; et al. Broad and potent neutralization of HIV-1 by a gp41-specific human antibody. Nature 2012, 491, 406-412. [CrossRef]

145. Gardner, M.R.; Fetzer, I.; Kattenhorn, L.M.; Davis-Gardner, M.E.; Zhou, A.S.; Alfant, B.; Weber, J.A.; Kondur, H.R.; Martinez-Navio, J.M.; Fuchs, S.P.; et al. Anti-drug antibody responses impair prophylaxis mediated by AAV-delivered HIV-1 broadly neutralizing antibodies. Mol. Ther. 2019, 27, 650-660. [CrossRef]

146. Kishimoto, T.K.; Ferrari, J.D.; LaMothe, R.A.; Kolte, P.N.; Griset, A.P.; O’Neil, C.; Chan, V.; Browning, E.; Chalishazar, A.; Kuhlman, W.; et al. Improving the efficacy and safety of biologic drugs with tolerogenic nanoparticles. Nat. Nanotechnol. 2016, 11, 890-899. [CrossRef]

147. Maldonado, R.A.; LaMothe, R.A.; Ferrari, J.D.; Zhang, A.-H.; Rossi, R.J.; Kolte, P.N.; Griset, A.P.; O’Neil, C.; Altreuter, D.H.; Browning, E.; et al. Polymeric synthetic nanoparticles for the induction of antigen-specific immunological tolerance. Proc. Natl. Acad. Sci. USA 2015, 112, E156-E165. [CrossRef]

148. Meliani, A.; Boisgerault, F.; Hardet, R.; Marmier, S.; Collaud, F.; Ronzitti, G.; Leborgne, C.; Costa Verdera, H.; Simon Sola, M.; Charles, S.; et al. Antigen-selective modulation of AAV immunogenicity with tolerogenic rapamycin nanoparticles enables successful vector re-administration. Nat. Commun. 2018, 9. [CrossRef]

149. Shin, J.-H.; Yue, Y.; Smith, B.; Duan, D. Humoral immunity to AAV-6, 8, and 9 in normal and dystrophic dogs. Hum. Gene Ther. 2012, 23, 287-294. [CrossRef]

150. Murphy, S.L.; Li, H.; Zhou, S.; Schlachterman, A.; High, K.A.; High, K. Prolonged susceptibility to antibody-mediated neutralization for adeno-associated vectors targeted to the liver. Mol. Ther. 2008, 16, 138-145. [CrossRef]

151. Rapti, K.; Louis-Jeune, V.; Kohlbrenner, E.; Ishikawa, K.; Ladage, D.; Zolotukhin, S.; Hajjar, R.J.; Weber, T. Neutralizing antibodies against AAV serotypes 1, 2, 6, and 9 in sera of commonly used animal models. Mol. Ther. 2012, 20, 73-83. [CrossRef]

152. Wang, L.; Calcedo, R.; Bell, P.; Lin, J.; Grant, R.L.; Siegel, D.L.; Wilson, J.M. Impact of pre-existing immunity on gene transfer to nonhuman primate liver with adeno-associated virus 8 vectors. Hum. Gene Ther. 2011, 22, 1389-1401. [CrossRef]

153. Elmore, Z.C.; Oh, D.K.; Simon, K.E.; Fanous, M.M.; Asokan, A. Rescuing AAV gene transfer from neutralizing antibodies with an IgG-degrading enzyme. JCI. Insight 2020, 5. [CrossRef]

154. Tse, L.V.; Klinc, K.A.; Madigan, V.J.; Castellanos Rivera, R.M.; Wells, L.F.; Havlik, L.P.; Smith, J.K.; Agbandje-McKenna, M.; Asokan, A. Structure-guided evolution of antigenically distinct adeno-associated virus variants for immune evasion. Proc. Natl. Acad. Sci. USA 2017, 114, E4812-E4821. [CrossRef] [PubMed]

155. Li, C.; Wu, S.; Albright, B.; Hirsch, M.; Li, W.; Tseng, Y.-S.; Agbandje-McKenna, M.; McPhee, S.; Asokan, A.; Samulski, R.J. Development of patient-specific AAV vectors after neutralizing antibody selection for enhanced muscle gene transfer. Mol. Ther. 2016, 24, 53-65. [CrossRef]

156. Auricchio, A.; O'Connor, E.; Weiner, D.; Gao, G.-P.; Hildinger, M.; Wang, L.; Calcedo, R.; Wilson, J.M. Noninvasive gene transfer to the lung for systemic delivery of therapeutic proteins. J. Clin. Investig. 2002, 110, 499-504. [CrossRef]

157. Limberis, M.P.; Wilson, J.M. Adeno-associated virus serotype 9 vectors transduce murine alveolar and nasal epithelia and can be readministered. Proc. Natl. Acad. Sci. USA 2006, 103, 12993-12998. [CrossRef]

158. Masat, E.; Pavani, G.; Mingozzi, F. Humoral immunity to AAV vectors in gene therapy: Challenges and potential solutions. Discov. Med. 2013, 15, 379-389. 
159. Manning, W.C.; Zhou, S.; Bland, M.P.; Escobedo, J.A.; Dwarki, V. Transient immunosuppression allows transgene expression following readministration of adeno-associated viral vectors. Hum. Gene Ther. 1998, 9, 477-485. [CrossRef]

160. Stasi, R.; Provan, D. Management of immune thrombocytopenic purpura in adults. Mayo Clin. Proc. 2004, 79, 504-522. [CrossRef]

161. Nathwani, A.C.; Gray, J.T.; Ng, C.Y.C.; Zhou, J.; Spence, Y.; Waddington, S.N.; Tuddenham, E.G.D.; Kemball-Cook, G.; McIntosh, J.; Boon-Spijker, M.; et al. Self-complementary adeno-associated virus vectors containing a novel liver-specific human factor IX expression cassette enable highly efficient transduction of murine and nonhuman primate liver. Blood 2006, 107, 2653-2661. [CrossRef]

162. Corti, M.; Elder, M.; Falk, D.; Lawson, L.; Smith, B.; Nayak, S.; Conlon, T.; Clément, N.; Erger, K.; Lavassani, E.; et al. B-cell depletion is protective against anti-AAV capsid immune response: A human subject case study. Mol. Ther. Methods Clin. Dev. 2014, 1. [CrossRef]

163. Mingozzi, F.; Chen, Y.; Edmonson, S.C.; Zhou, S.; Thurlings, R.M.; Tak, P.P.; High, K.A.; Vervoordeldonk, M.J. Prevalence and pharmacological modulation of humoral immunity to AAV vectors in gene transfer to synovial tissue. Gene Ther. 2013, 20,417-424. [CrossRef]

164. Halbert, C.L.; Standaert, T.A.; Wilson, C.B.; Miller, A.D. Successful readministration of adeno-associated virus vectors to the mouse lung requires transient immunosuppression during the initial exposure. J. Virol. 1998, 72, 9795-9805. [CrossRef]

165. Bouvet, M.; Fang, B.; Ekmekcioglu, S.; Ji, L.; Bucana, C.D.; Hamada, K.; Grimm, E.A.; Roth, J.A. Suppression of the immune response to an adenovirus vector and enhancement of intratumoral transgene expression by low-dose etoposide. Gene Ther. 1998, 5, 189-195. [CrossRef]

166. Guilbaud, M.; Devaux, M.; Couzinié, C.; Le Duff, J.; Toromanoff, A.; Vandamme, C.; Jaulin, N.; Gernoux, G.; Larcher, T.; Moullier, P.; et al. Five years of successful inducible transgene expression following locoregional adeno-associated virus delivery in nonhuman primates with no detectable immunity. Hum. Gene Ther. 2019, 30, 802-813. [CrossRef]

167. Fisher, K.J.; Jooss, K.; Alston, J.; Yang, Y.; Haecker, S.E.; High, K.; Pathak, R.; Raper, S.E.; Wilson, J.M. Recombinant adeno-associated virus for muscle directed gene therapy. Nat. Med. 1997, 3, 306-312. [CrossRef]

168. Herzog, R.W.; Hagstrom, J.N.; Kung, S.-H.; Tai, S.J.; Wilson, J.M.; Fisher, K.J.; High, K.A. Stable gene transfer and expression of human blood coagulation factor IX after intramuscular injection of recombinant adeno-associated virus. Proc. Natl. Acad. Sci. USA 1997, 94, 5804-5809. [CrossRef]

169. Zhu, J.; Huang, X.; Yang, Y. The TLR9-MyD88 pathway is critical for adaptive immune responses to adeno-associated virus gene therapy vectors in mice. J. Clin. Investig. 2009, 119, 2388-2398. [CrossRef]

170. Sudres, M.; Ciré, S.; Vasseur, V.; Brault, L.; Da Rocha, S.; Boisgérault, F.; Le Bec, C.; Gross, D.A.; Blouin, V.; Ryffel, B.; et al. MyD88 signaling in B cells regulates the production of Th1-dependent antibodies to AAV. Mol. Ther. 2012, 20, 1571-1581. [CrossRef]

171. Rogers, G.L.; Suzuki, M.; Zolotukhin, I.; Markusic, D.M.; Morel, L.M.; Lee, B.; Ertl, H.C.J.; Herzog, R.W. Unique roles of TLR9- and MyD88-dependent and -independent pathways in adaptive immune responses to AAV-mediated gene transfer. JIN 2015, 7, 302-314. [CrossRef] [PubMed]

172. Hösel, M.; Broxtermann, M.; Janicki, H.; Esser, K.; Arzberger, S.; Hartmann, P.; Gillen, S.; Kleeff, J.; Stabenow, D.; Odenthal, M.; et al. Toll-like receptor 2-mediated innate immune response in human nonparenchymal liver cells toward adeno-associated viral vectors. J. Hepatol. 2012, 55, 287-297. [CrossRef]

173. Martino, A.T.; Suzuki, M.; Markusic, D.M.; Zolotukhin, I.; Ryals, R.C.; Moghimi, B.; Ertl, H.C.J.; Muruve, D.A.; Lee, B.; Herzog, R.W. The genome of self-complementary adeno-associated viral vectors increases Toll-like receptor 9-dependent innate immune responses in the liver. Blood 2011, 117, 6459-6468. [CrossRef] [PubMed]

174. Faust, S.M.; Bell, P.; Cutler, B.J.; Ashley, S.N.; Zhu, Y.; Rabinowitz, J.E.; Wilson, J.M. CpG-depleted adeno-associated virus vectors evade immune detection. J. Clin. Investig. 2013, 123, 2994-3001. [CrossRef]

175. Mou, H.; Zhong, G.; Gardner, M.R.; Wang, H.; Wang, Y.-W.; Cheng, D.; Farzan, M. Conditional regulation of gene expression by ligand-induced occlusion of a microRNA target qequence. Mol. Ther. 2018, 26, 1277-1286. [CrossRef]

176. Marceau, C.D.; Negi, S.S.; Hernandez, H.; Callison, J.; Marzi, A.; Borisevich, V.; Berry, J.; Feldmann, H.; Rockx, B. Novel neutralizing monoclonal antibodies protect rodents against lethal filovirus challenges. Trials Vaccinol. 2014, 3, 89-94. [CrossRef] 
177. Strohl, W.R. Current progress in innovative engineered antibodies. Protein Cell 2018, 9, 86-120. [CrossRef]

178. Gu, J.; Ghayur, T. Generation of dual-variable-domain immunoglobulin molecules for dual-specific targeting. Methods Enzymol. 2012, 502, 25-41. [CrossRef]

179. Cerulli, R.A.; Kritzer, J.A. Stringing together a universal influenza antibody. Biochemistry 2019, 58, $1943-1944$. [CrossRef] [PubMed]

Publisher's Note: MDPI stays neutral with regard to jurisdictional claims in published maps and institutional affiliations.

(C) 2020 by the authors. Licensee MDPI, Basel, Switzerland. This article is an open access article distributed under the terms and conditions of the Creative Commons Attribution (CC BY) license (http://creativecommons.org/licenses/by/4.0/). 